\title{
La codificación civil y los derechos forales (1808-1833)
}

\section{The civil codification and the historical rights (1808-1833)}

\author{
Emilio Javier DE BENITO FRAILE \\ Profesor Titular de Historia del Derecho \\ Departamento de Historia del Derecho. Facultad de Derecho \\ Universidad Complutense de Madrid \\ emibe@der.ucm.es
}

Recibido: 15 de diciembre de 2011

Aceptado: 3 de febrero de 2012

\begin{abstract}
RESUMEN
La codificación civil española fue la más tardía de todas. Diversos factores incidieron en esta tardanza: factores políticos, sociales, e interconectada con los mismos, la existencia de una diversidad jurídica que se resistía a desaparecer. Estamos acostumbrados a que se haya restado importancia a esta resistencia ejercida durante la primera mitad del siglo XIX. Ahora bien, si es cierto, que la fortaleza y articulación que caracteriza a la misma durante la segunda mitad del siglo no es comparable con la que se produce en el periodo anterior, ello no quiere decir ausencia, sino que circunstancias de distinta índole impidieron su concreción y manifestación, pero ahí estaba y cuando dichas circunstancias desaparecen, se exterioriza abiertamente.
\end{abstract}

PALABRAS CLAVE: Codificación civil, derechos forales, unificación, Vizcaya, Guipúzcoa, Álava, Navarra, Cataluña.

\begin{abstract}
The Spanish civil codification was the latest of all. Several factors led to this delay: political and social matters, and, interconnected therewith, the existence of a legal diversity that refused to give way. We are used to play down this resistance exerted during the first half of the $19^{\text {th }}$ century. However, while it is true that the strength and articulation that characterizes the same resistance during the second half of the century is not comparable to the one produced in the previous period, this does not mean the absence of it. There were circumstances of different nature that prevented its realization and demonstration, but nevertheless it was there, and as soon as those circumstances disappeared, it was openly exteriorized.
\end{abstract}

KEYWORDS: Civil Codification. Historical rights, Unification, Vizcaya, Guipúzcoa, Álava, Navarra, Catalonia.

\section{RÉSUMÉ}

La codification civil espagnole a été la dernière de toutes. Plusieurs facteurs ont conduit à ce retard : des raisons politiques et sociales, ainsi que l'existence d'une diversité juridique très importante et qui refuse de disparaître. Nous sommes habitués à a minimiser cette résistance exercée au cours de la pre- 
mière moitié du XIX ${ }^{\mathrm{e}}$ siècle. Cependant, s'il est vrai que la force et l'articulation qui caractérise cette résistance au cours de la seconde moitié du siècle n'est pas comparable à celle produite dans la période précédente, tout de même cela ne signifie pas absence, mais simplement que des circonstances d'un tout autre ordre auraient empêché sa réalisation et démonstration. Tout de même, la résistance était là, et aussitôt les circonstances disparaissent, elle se manifeste ouvertement.

MOTS CLÉ : Codification civile, Droits forals, Unification, Vizcaya, Guipúzcoa, Álava, Navarra, Catalogne.

\section{ZUSAMMENFASSUNG}

Die spanische Zivilrechtskodifikation war die wohl späteste überhaupt, wozu es verschiedene Gründe gibt: politische Faktoren, soziale und mit beiden verklammert, das Bestehen einer juristischen Vielfalt, die nicht aufhören wollte weiterzubestehen. In der ersten Hälfte des 19. Jahrhunderts war diese Bewegung, wie allseits bekannt, sehr stark. Wenn nun sicher ist, dass die Stärke und Wortgewalt, mit der diese sich in der zweiten Hälfte des Jahrhunderts auszeichnet, mit derjenigen der vorangegangenen Zeit nicht vergleichbar ist, dann heißt dies nicht automatisch, dass es zunächst keine solche Bewegung gegeben hatte. Vielmehr verhinderten Umstände ganz verschiedener Natur das Auftreten und das Wirken dieser Bewegung. Sie war indes vorhanden und trat mehr und mehr ans Tageslicht.

SCHLÜSSELWÖRTER: Zivilrechtskodifikation, Foralrechte, Rechtsvereinheitlichung, Vizcaya, Guipúzcoa, Álava, Navarra, Katalonien.

SUMARIO: 1. Introducción. 2. Descripción y análisis de los acontecimientos. 3. Conclusiones.

\section{Introducción}

Es por todos conocido, el largo y conflictivo proceso en el que se vio inmersa la codificación civil española. Nuestro Código Civil, contrariamente a lo que había sucedido en el país vecino, fue el último en promulgarse.

Muchas son las razones que se han esgrimido para explicar este retraso de nuestra codificación civil. No cabe duda que factores de índole social y político incidieron de forma importante ${ }^{1}$, pero también e interconectada con éstos existió una resistencia de los territorios con derecho propio a renunciar al mismo. Resistencia, posiblemente, no tanto en contra de la unificación consagrada en los textos constitucionales, como en la forma en que ésta debería llevarse a cabo.

Es una evidencia aceptada por la práctica totalidad de los autores, que una oposición decidida, firme y compacta en contra del sistema elegido para codificar el derecho civil, no se manifiesta hasta los inicios de la segunda mitad del siglo XIX.

\footnotetext{
${ }^{1}$ La falta de unidad social que caracterizaba a la España de principios del siglo XIX, así como la pugna existente entre partidarios y enemigos del Nuevo Régimen, fueron aspectos a tener también muy en cuenta e incidieron notablemente en la mayor o menor defensa de los ordenamientos particulares, retrasando la codificación civil. En este sentido se expresan, M. Duran y Bas, Escritos. Primera Serie. Estudios Jurídicos, Barcelona, 1888, p. 287, así como S. Salvador y Cordech, El Proyecto del Código Civil de 1851 y El Derecho Civil Catalán, en Revista Jurídica de Cataluña, 1, 1980 (enero-marzo), p. 50.
} 
Extremo que, por otro lado, no nos debe extrañar, dado que es en este momento cuando aparecen las primeras realizaciones concretas a las que oponerse ${ }^{2}$, al no haberse producido hasta ese momento una situación similar.

¿Que este movimiento compacto no se hubiera constituido de forma ostensible hasta esas fechas, significaba, por el contrario, la anuencia de los territorios con derecho propio a la pérdida de sus instituciones particulares? Creo que la respuesta es negativa. Autores, tan destacados como Juan Pablo Fusi, refiriéndose a las provincias Vascongadas y Navarra, ya destaca la existencia en la segunda mitad de la década de los años treinta de un movimiento claro y definido en contra de la unificación y por ende de defensa de su particularismo jurídico en un sentido amplio ${ }^{3}$. En otros términos, el prof. Lalinde, con respecto de Cataluña, y en este caso aludiendo expresamente al derecho privado, nos habla de la existencia de un divorcio entre las concepciones jurídicas catalanas y castellanas, acontecida de forma tenue durante las primeras décadas del siglo para crecer especialmente en la segunda mitad ${ }^{4}$.

Este panorama esgrimido por los autores anteriormente citados está en línea con otros muchos pronunciamientos defendidos por tantos otros para el ámbito de las provincias Vascongadas y Navarra, en los que aun corroborando la segunda mitad de la década de los treinta para poder hablar de un fuerismo, como movimiento contra la unificación, no por ello dejan de admitir la existencia de un sentimiento regionalista $a_{\text {antior }}^{5}$, que por distintas circunstancias que operaban en esos momentos, impedían su articulación y una respuesta más amplia y consolidada.

Estoy de acuerdo prácticamente en su totalidad con los argumentos anteriormente expuestos. Ahora bien, considero, más en la línea de los últimos, que el sentimiento foralista en los territorios antes mencionados existió siempre, pero que las realidades

\footnotetext{
${ }^{2}$ Tanto en el Estatuto de Bayona como en la Constitución de 1812 había quedado consagrado la unidad de códigos, extremo que encontró cierta contestación por parte de los territorios con derecho propio, principalmente, las Provincias Vascongadas, Navarra y Cataluña, pero hasta ese momento, con la excepción del proyecto de Código Civil de 1821, inacabado, no se había logrado ningún resultado efectivo en orden al desarrollo de tal principio constitucional.

${ }^{3}$ J.P. Fusi Aizpurúa, Constitución y Fueros: Análisis político de un debate secular, en Jornadas de estudios sobre la actualización de los Derechos Históricos Vascos, celebradas en San Sebastián, 1985, Bilbao, 1986, pp. 225 y 226

${ }^{4}$ Es cierto que el Prof. Lalinde basándose en tales pronunciamientos llega a la conclusión de que si la codificación se hubiera llevado a cabo inmediatamente, en las primeras décadas del siglo XIX, hubiera sido probable que hubiera "arrastrado en su vorágine al derecho catalán" (J. Lalinde Abadía, Estudio del Art. $1^{\circ}$ de la Compilación del Derecho Civil Especial (Alerta a la Escuela Histórica), en Revista Jurídica de Cataluña, 1961, p. 254). Al margen de las conclusiones a las que llega, no por ello deja de reconocer la existencia de este divorcio y la presencia de un historicismo catalán, aunque no tan acentuados como se mostrarían después.

${ }^{5}$ Coro Rubio Pobes, Revolución y tradición. El País Vasco ante la Revolución liberal y la construcción del Estado español, 1808-1868, Madrid, 1996, p. 128. Aitziber Irigoras Alberdi, Derechos históricos vascos y constitucionalismo español: foralidad y sistema jurídico liberal en el siglo XIX, Oñati, 2008, p. 32. J. Camps y Arboix, Historia del Derecho catalán moderno, Barcelona, 1958, pp. 65 у 66.
} 
actuantes no permitieron, ni precisaron una contestación más contundente. Realidades como fueron:

— La situación política del país, sometido a un gobierno extranjero.

- La falta, muy generalizada, de una real comprensión del significado y alcance de los principios liberales en que se inspiraban las tendencias unificadoras.

- La ausencia de aplicación y desarrollo de los postulados constitucionales, debido a las convulsiones políticas en que está inmerso el país durante las primeras décadas del siglo, lo que implicó un desconocimiento absoluto del alcance efectivo de las reformas a realizar.

- Y en íntima conexión con la anterior, la inexistencia de iniciativas concretas en el campo de la codificación civil.

Todas estas circunstancias, en su conjunto, incidieron, desde mi punto de vista, de forma considerable en el grado de la contestación, al margen del sentimiento regionalista arraigado en los citados territorios.

La interferencia de las anteriores circunstancias en la mayor o menor resistencia opuesta a las reformas, lo que no significó, en momento alguno, su aceptación sin límites y el modo de llevarse a cabo las mismas, es el tema sobre el que voy a tratar de aportar alguna reflexión con el objeto de lograr, si así lo consigo, un mayor acercamiento a la realidad foralista. Para ello procederé a examinar y analizar los distintos acontecimientos de interés que se producen desde 1808 a 1833. Acontecimientos, la mayor parte de ellos, que se corresponden a actuaciones en el ámbito del derecho público y en los territorios Vascongados y Navarra, como consecuencia lógica de que son a este campo al que corresponden las primeras medidas que comienzan a llevarse a efecto, pero que con las salvedades necesarias y siendo consciente de que se trata de una realidad muy diferente, creo que nos pueden ofrecer un termómetro del sentimiento de resistencia existente hacia las reformas en general, que se concretará más tarde en el ámbito del derecho privado, una vez que se proceda a realizar las primeras actuaciones con respecto del mismo.

\section{Descripción y análisis de los acontecimientos}

Será la Constitución de Bayona ${ }^{6}$, el primer texto que consagra la unidad de Códigos para España e Indias ${ }^{7}$, aunque en su art. 144, establecía que los fueros particulares de las provincias de Navarra, Vizcaya, Guipúzcoa y Álava se examinarían en las primeras Cortes, para determinar lo que se juzgara más conveniente al interés de

\footnotetext{
${ }^{6}$ Los constitucionalistas actuales optan por denominar al texto promulgado en Bayona como "Estatuto" o "Carta otorgada", al no considerarlo técnicamente, de acuerdo con la dogmática constitucional moderna, como una auténtica Constitución. Ahora bien, los documentos contemporáneos al referirse al mismo lo califican como Constitución, al tratarse de la ley fundamental del Estado. Esta es la razón de que en este caso, fieles a los documentos de la época, sea utilizado por nosotros la acepción "Constitución".

${ }^{7}$ Arts. 96 y 113.
} 
las mismas provincias y al de la nación. Ateniéndonos a la redacción constitucional, en la misma quedan plasmadas las ideas codificadoras presentes en el resto del continente europeo, aunque también es verdad que, como señalamos anteriormente, en su art. 144, se prevé el tratamiento posterior de las cuestiones relacionadas con las provincias de Navarra, Vizcaya, Guipúzcoa y Álava.

Este último extremo no contemplado en los primeros proyectos, se incorporaría al texto definitivo, posiblemente, como una cesión interesada del Emperador a estos territorios, que habían manifestado su resistencia a la pérdida de sus particulares ordenamientos jurídicos, con el fin de mantener con los mismos unas buenas relaciones. Una sintonía que facilitara la consecución, con los menores traumas posibles, del proyecto imperial de anexionar los mismos al reino de Francia. Esta sería la razón de la inclusión del citado art. 144 en el texto constitucional, que no hacía más que aplazar la decisión para su tratamiento posterior, lo que indicaría la intención oculta de Napoleón de acabar con las peculiaridades de que gozaban los citados territorios ${ }^{8}$.

La incorporación del mencionado art. 144, sin embargo, facilitó la votación y aprobación sin reservas del texto constitucional, al considerar que en el mismo quedaban recogidas las pretensiones de estos territorios de mantener sus sistemas forales. Prueba evidente de la actitud de los mismos en lo que se refiere a la defensa de sus derechos y oposición a una posible unificación. Todo ello se puede constatar, con respecto a los mencionados territorios y en menor medida a Cataluña, a lo largo del proceso de elaboración del texto constitucional, que pasamos a analizar a continuación.

La primera mención expresa a los códigos, la encontramos en la Comisión designada por la Junta Provisional, conformada por los diputados que iban llegando a Bayona; y de manera más puntual, en los informes emitidos por los Consejeros de Castilla en los que, como respuesta a la inclusión en el primer proyecto del texto constitucional del Código de Napoleón ${ }^{9}$, destacan la necesidad de que para la elaboración de los mismos se tuviese en cuenta el derecho tradicional español ${ }^{10}$. Informe que, al parecer, irritó al Emperador ${ }^{11}$. Con anterioridad, Urquijo ya había remitido al mismo un escrito, en el que se aludía al apego de las provincias Vascongadas y Na-

\footnotetext{
${ }^{8}$ María Reyes Agudo, El Estatuto de Bayona, Recurso Electrónico, Universidad Complutense de Madrid, Servicio de Publicaciones, 2006, pp. 388-390. R. Jiménez Asensio, Apuntes para una historia del Constitucionalismo Español, Colección Itxaropena, Zarautz, 1992, p. 45. María Cruz Mina Apat, Fueros y revolución liberal en Navarra, Madrid, 1981, p. 62.

${ }^{9}$ El art. 53 del primer proyecto establecía: El Código de Napoleón formará las leyes civiles del reino. El deseo de aplicar el citado código en España no resulta novedoso, teniendo en cuenta que en algunos territorios dominados por miembros de la familia Bonaparte, como era el caso de Holanda, ya habían adoptado el mismo, en Domínguez Agudo, El Estatuto de Bayona..., p. 229.

${ }^{10}$ I. Fernández Sarasola, considera que la desaparición del Código de Napoleón del articulado se debió a esa observación, presentada por el Consejo de Castilla, que no se conformaba con que se derogase toda la legislación tradicional en La Constitución de Bayona (1808), Colección Las Constituciones Españolas, dirigida por Miguel Artola, Madrid, 2007, p. 48.

${ }^{11}$ C. Sanz Cid, La Constitución de Bayona: labor de redacción y elementos que a ella fueron aportados, Madrid, 1922, pp. 226-231.
} 
varra a sus instituciones, y que, al parecer, no surtió efecto alguno, pero que, sin embargo, tal y como señala Irigoras Alberdi, puede servirnos como indicador de cuál era el grado de su sentimiento foralista ${ }^{12}$.

De nuevo se vuelve a insistir, e incluso de forma más explícita a la cuestión de los derechos forales, en la memoria redactada por el Ayuntamiento de Barcelona conteniendo las instrucciones al diputado nombrado por la Corporación a las Cortes de $\mathrm{Ba}$ yona, en la que se reclamaba de forma expresa el respeto hacia los mismos "que en todas las provincias que tienen fueros particulares, se guarden éstos religiosamente por todos los Tribunales..." ${ }^{\prime 13}$. Esta defensa de los derechos particulares no sólo proviene de las instituciones, sino que como señala, Camps y Arboix, los propios abogados catalanes de 1808, a pesar de numerosos casos de condescendencia e incluso de afrancesamiento, opusieron una gran resistencia a los intentos del emperador. Actitud que prueba, según el citado autor, la vitalidad de sus propios ordenamientos legales ${ }^{14}$.

La afección a sus instituciones propias, frente a lo que podía suponer el contenido del texto constitucional en su conjunto, queda constatado, asimismo, en el encargo expreso otorgado por las juntas generales de Vizcaya y Guipúzcoa a sus representantes en la Asamblea de Bayona, Juan José $\mathrm{M}^{\mathrm{a}}$ de Yandiola y José $\mathrm{M}^{\mathrm{a}}$ de Lardizábal, respectivamente, quienes debían velar por la observancia de los fueros en toda su integridad y extensión. Es significativo, en este sentido, el escrito enviado por Yandiola a su diputación el mismo día de la apertura de la Asamblea: "Debo comunicar a V.S.S. que existe una Constitución que se presentará en la asamblea bien pronto. ¡Cual ha sido mi sorpresa y la aflicción de mi corazón cuando he sabido que es general para toda la España y que las Provincias Vascongadas no se distinguirán de las demás!... ${ }^{15}$. Los miedos esgrimidos por Yandiola no tardaron en confirmarse. En el proyecto de Constitución los fueros quedaban suprimidos, aunque, merced a la intervención del ministro Urquijo, esta disposición quedaría finalmente excluida.

Cuando en la sesión de 27 de junio se procedió a la votación, punto por punto, del texto constitucional, Yandiola declaró ante la Asamblea que había enviado al Emperador una representación solicitándole la conservación de los fueros y constituciones particulares del Señorio, de forma que su asistencia a la reunión no debía interpretarse como

\footnotetext{
${ }^{12}$ Irigoras Alberdi, Derechos históricos vascos y constitucionalismo español: foralidad..., p. 32. Sentimiento foralista que, sin embargo, no detecta Miguel Artola, quien, al menos en 1959, destacaba la existencia en 1808 de un sentimiento unánime antifuerista, incluso en las provincias exentas; para más tarde, en 1989, dar la impresión de que se contradice de su afirmación anterior, al referirse a las ideas concebidas por Napoleón con respecto de las citadas provincias y aludir a un contraproyecto ordenado por la corte española a Izquierdo, en el que, además, de hacer grandes concesiones al emperador, en el mismo se recoge lo que sigue: " he hecho una fiel pintura del horror que causaría a los pueblos cercanos al Pirineo la pérdida de sus leyes, libertades, fueros y lengua...", en Los Orígenes de la España Contemporánea, Madrid, 1959, I, p. 30, y Los afrancesados, Madrid, 1989, p. 80, respectivamente.

${ }^{13}$ Camps y Arboix, Historia del Derecho catalán..., pp. 65 y 66.

${ }^{14}$ Ibidem.

${ }^{15}$ Rubio Pobes, Revolución y tradición. El País Vasco ante la Revolución liberal, p. 130.
} 
una adhesión formal a la ley general que se aprobase en la misma. Declaración, a la que se sumaron los diputados de Guipúzcoa, Álava, Navarra e incluso el de Cataluña.

En las exposiciones dirigidas al Emperador ${ }^{16}$, en defensa de sus derechos, por los territorios citados, además de expresar su respeto a la Constitución en su sentido más amplio; en algunas de ellas, al tratar pormenorizadamente su articulado, junto con otras cuestiones particulares, manifiestan expresamente sus reservas a la unidad de códigos $^{17}$. Este es el caso de Navarra ${ }^{18}$, Guipúzcoa ${ }^{19} \mathrm{o}$ Vizcaya $^{20}$.

Independientemente de las declaraciones antes señaladas, en el momento de proceder a la votación del artículo que recogía la unidad de códigos en el ámbito civil, ampliada por enmienda al ámbito criminal, éste fue aprobado por unanimidad, no planteándose oposición alguna por parte de los representantes de los territorios forales; quienes contrariamente habían elevado, con anterioridad, su protesta acerca del contenido no solo de dicho artículo, sino contra la totalidad del texto en sus representaciones al Emperador. Para Irigoras Alberdi ${ }^{21}$, este comportamiento contradictorio de los representantes de los territorios forales, podría explicarse, como ya señalábamos más arriba, al considerar que con la inclusión en la nueva Carta del art. 144, anteriormente enunciado, quedaban recogidas sus pretensiones relativas al mantenimiento de los sistemas forales y, por tanto, aceptada su protesta. Al margen de cualquier consideración, la realidad es que los diputados vascos junto con el resto estamparon su firma en el mismo. Habían logrado, aunque fuera solo formalmente, que los fueros de las provincias Vascongadas y Navarra no fueran suprimidos explícitamente.

Por último, creo que para una mayor comprensión de la situación que se vivió frente a las tendencias unificadoras recogidas en el texto constitucional, y poder valorar con mayor precisión la dimensión de la respuesta hacia las mismas, es necesario considerar otra serie de factores que pueden contribuir a aproximarnos a una idea más completa de la realidad. En primer lugar, pienso que la autoridad imperial, la fi-

\footnotetext{
${ }^{16}$ Las citadas exposiciones se recogen en las Actas de sesiones del día 27 de junio, a excepción de la de Cataluña, por la negativa del presidente: "El Sr. D. José Garriga pretendió hacer otra igual por el Principado de Cataluña; pero el Sr. Presidente le hizo observar que ni había sido nombrado por el Principado mismo, que era el caso de los otros Diputados, ni la Cataluña tenía una Constitución particular", en Diario de Sesiones de la Asamblea de Bayona, sesión de 27 de junio de 1808, p. 38. Ver también a este respecto, Irigoras Alberdi, Derechos históricos vascos y constitucionalismo español: foralidad y sistema jurídico liberal en el siglo XIX, Oñati, 2008, p. 37.

${ }^{17}$ Según indica Irigoras Alberdi, "los puntos conflictivos para los territorios forales eran, básicamente, la unidad de códigos, la igualdad contributiva y la supresión de las aduanas interiores”, en op. cit., p. 36.

18 “Asimismo en cuanto se ordena por el art. 87, que la España se gobernará por un solo Código de leyes civiles”, en Diario de Sesiones de la Asamblea de Bayona, sesión de 27 de junio de 1808, p. 106.

19 “'3a, El art. 87 del tít. 11, que previene que la España se gobierne por un solo Código de leyes civiles, cuando Guipúzcoa tiene particulares leyes pactadas al tiempo de la entrada voluntaria”, en Ibidem, p. 108. 20 "Aunque el establecimiento de un solo Código de leyes civiles, que se prescribe en el art. 87, tit. $9^{\circ}$ de la expresada Constitución, presenta una utilidad general, no es aplicable a Vizcaya, así por su independencia, cuanto por concurrir en ella diversas circunstancias que en el resto del Reino", en Ibidem, p. 109. ${ }^{21}$ Irigoras Alberdi, op. cit., p. 38.
} 
gura de Napoleón, en muchos casos, limitó o redujo el tono de la contestación, como muy bien destaca Rubio Pobes ${ }^{22}$, quien aludiendo a la convocatoria para asistir a la asamblea de Bayona, señala lo siguiente: "Las autoridades vascas, impresionadas, o más bien asustadas, por el hecho de que el invencible Napoleón les convocara a una reunión política, decidieron sin más objeciones enviar sus representantes a Bayona". Palabras que no dejan lugar a dudas sobre la actitud de los representantes vascos, quienes evitarían en todo momento una confrontación directa con el emperador. Por otro lado, tal y como menciona Sanz $\mathrm{Cid}^{23}$, es importante valorar el escaso conocimiento que caracterizó a los diputados presentes en la Asamblea de Bayona acerca de las doctrinas políticas presupuestas por el nuevo sistema constitucional, así como de las leyes que en algunos países las habían desenvuelto. Falta de conocimientos, sigue diciendo el citado autor, que les impidió "cohonestar los nuevos principios del constitucionalismo, con los elementos de la tradición política de España, dando así al nuevo régimen, que pretendía instaurarse, una continuidad".

De cualquier manera, el nuevo orden consagrado en la Constitución prácticamente no trascendió del orden teórico. La situación que atravesaba el país y los sucesivos acontecimientos que se producen, impidieron el desarrollo de la misma, y por tanto, su efectividad práctica fue bastante escasa.

Ocupada España por los franceses, las juntas provinciales que habían asumido el gobierno de sus respectivos territorios ante la desintegración del Estado, se constituyen en Junta Suprema Central y Gubernativa del Reino. Tal y como señala Camps y Arboix, los componentes de la Junta Superior de Cataluña, algunos de los cuales integrarían posteriormente la Central, debían jurar fidelidad a la religión, a Fernando VII, a ayudar a las otras provincias de España, a procurar su unión bajo una sola y misma autoridad y mantener las leyes, exenciones, privilegios y buenas costumbres de Cataluña ${ }^{24}$.

El 22 de mayo de 1809, la recién creada Junta Suprema Central promulgaba un Real Decreto sobre restablecimiento de las Cortes, en el que se aprueba, asimismo, realizar una consulta al país para que emitiera su opinión sobre diversos aspectos,

\footnotetext{
${ }^{22}$ Rubio Pobes, Revolución y tradición. El País Vasco ante la Revolución liberal..., pp. 128 y 129.

${ }^{23}$ El citado autor destaca, como claro ejemplo de esta falta de preparación, las propias opiniones emitidas por la comisión designada, a instancias del emperador, por "personas juzgadas como capaces de formar una opinión sobre el estatuto...”, de la que formaban parte: El General O'Farril, ministro de Guerra; Piñuela, ministro de Gracia y Justicia; el bailío Gil de Lemus, ministro de Marina; El Marqués de Caballero, consejero de Estado y gobernador del Consejo de Hacienda; el Conde de Montarco, consejero de Estado; el Marqués de las Amarillas, consejero de Estado, presidente del Consejo de Guerra; Bernardo de Iriarte, Vicepresidente con Consejo de Indias; el Duque de Granada, presidente del Consejo de Órdenes; A. Mon y Velarde, decano del Consejo de Castila; Francisco Javier Durán y Navarro Vidal, del Consejo de Castilla, ambos; el Corregidor de Madrid y el Capitán General de Castilla la Nueva (Sanz Cid, La constitución de Bayona: labor de redacción y elementos que a ella fueron aportados..., Madrid, Reus, 1922, pp. 211, 382 y 383).

${ }^{24}$ Camps y Arboix, Historia del Derecho catalán..., p. 51.
} 
entre los que se encontraba los "Medios de mejorar nuestra legislación, desterrando los abusos introducidos y facilitando su perfección"25.

De las respuestas remitidas por las distintas autoridades, eclesiásticos y particulares, podemos deducir, al menos de forma aproximada, cuál era la concepción de la sociedad española acerca de la reformas que se debían emprender en la legislación, forma en que se debían llevar a cabo las mismas, así como la actitud existente con respecto a los derechos forales, extremo este último, objeto principal de este trabajo.

La valoración de las mismas realizada, hasta el momento, por los autores, no siempre coincidente, presenta el siguiente panorama:

Artola, quien ha analizado y publicado parte de estas respuestas ${ }^{26}$, no siempre con demasiada precisión y exactitud, llega a la conclusión de que en la mayoría de los casos se argumenta a favor de la unificación legal, siendo escasas e imprecisas las menciones que se encuentran en defensa de los fueros regionales; añadiendo que aún resulta más significativo, el hecho de no existir una localización geográfica de estos escritos, procediendo de todos los puntos de la península, incluso de las provincias que conservaban o habían mantenido hasta hacía relativamente poco tiempo una legislación propia ${ }^{27}$. Gibert, en un análisis más preciso, incide de nuevo en la idea de la casi unánime petición de un Código arreglado y justo, coincidiendo en la mayoría de los casos en la denuncia de los inveterados defectos de la Recopilación, pero destacando el escasísimo número de opinantes que insinúan los deseos de renovación de acuerdo con los ideales de la Ilustración. Asimismo, contradiciendo al primero, alude a las diferencias observadas en los distintos pronunciamientos en función de su origen territorial, señalando que: "los dictámenes originados en la Corona de Castilla se adhieren sin reservas a la idea de un solo Código para toda la nación. En cambio, Cataluña, Valencia y Mallorca señalan la tendencia a conservar y aun restablecer las particularidades de su derecho, que los Decretos de Felipe $\mathrm{V}$ habían reducido pero no anulado. En algún caso llega a proponerse que se permita a las provincias gobernarse por el código particular de cada una. En otros, más moderadamente, a mantener algunas notas, o bien a que los diferentes reinos sean consultados sobre el Código general, o bien que éste tome lo mejor de las legislaciones regionales" ${ }^{28}$.

\footnotetext{
${ }^{25}$ Para el Prof. F. Martínez Martínez los propios términos de la pregunta denotan la visión de la Junta encuestadora, que se inclina más hacia un proceso de reforma que de ruptura, en Repensar la Constitución de 1812: Cádiz o el imposible constituyente, Historia et ius, Rivista di Storia Giuridica dell'età medievale e moderna, www.historiaetius.eu, 3/2013, paper 6, p. 78.

${ }^{26}$ M. Artola, Los Orígenes de la España Contemporánea, Madrid, 1959, 2 vols.

${ }^{27}$ Ibidem, pp. 355. Ver también del mismo autor La España de Fernando VII, Madrid, 2008, pp. 326 y 327.

${ }^{28}$ R. Gibert, La Codificación Civil en España, en La formazione storica del diritto moderno en Europa, Atti del Terzo Congresso Internazionale della Società Italiana di Storia del Diritto, Firenze, 1977, vol. 2, pp. 909 y 910.
} 
Si bien es cierto que en la mayoría de los casos se defiende la idea de unificación lega ${ }^{29}$, como ya señalaron en su momento los autores anteriormente citados, son escasos los supuestos, como muy bien recoge Gibert, en los que se manifiesta una clara conciencia de Código unificado de acuerdo con los principios del iusnaturalismo racionalista, siendo, por el contrario, mayoría en las que se plantea una codificación como solución a los problemas derivados de la Novísima Recopilación; incidiendo, de nuevo, más en la idea de recopilación de leyes que del preciso sentido del término Código según el pensamiento liberal. "La multitud de nuestras leyes hace que éstas más bien confundan que dirijan a la equidad y a la justicia. Sean las leyes pocas, sólidas y sin la tenaz admisión de controversias. Las tenemos muy justas, arregladas y santas. Fórmese de ellas un claro y breve cuerpo, que se llame Constitución, Código o Instituciones de España e Indias" ${ }^{\prime 30}$, y por tanto, al menos desde mi punto de vista, sin renunciar por ello al mantenimiento de muchas de estas instituciones vigentes en los territorios forales; llegando a la unificación, a través de la armonización de las distintas instituciones, o bien recogidas éstas a modo de excepciones particulares. Este es el sentir que observamos en diferentes respuestas, como el caso del Cabildo de Tarragona, que se expresa en los siguientes términos: "Como uno de los mayores defectos de cualquier legislación sea la multitud y complicación de las leyes... parece necesario que se simplifiquen las de estos reinos... y que, en cuanto lo permitan los usos y costumbres razonables y justos de las provincias que tienen sus códigos municipales, sean aquéllas generales y trascendentales a todo el Reino"31. Lo que no se observa, al menos a mi entender, es la exis-

${ }^{29}$ Un ejemplo claro lo encontramos en la elocuente respuesta de Miguel Agustín Jarillo, quien se manifiesta en los siguientes términos: "Una nación, por grande que sea, debe conceptuarse una gran familia $y$, por consiguiente, debe haber en ella una sola legislación. Una nación que tiene algunas provincias con diversos fueros, es una cosa monstruosa. La nación española, aunque es un vasto reino compuesto de diversas provincias, puede y debe gobernarse por unas leyes generales y uniformes, porque en todas se habla una misma lengua, se profesa una misma religión, se notan las mismas costumbres y tiene una sola cabeza suprema. Circunstancias que contribuyen a que sea gobernada por una sola legislación, sin que sea alterada por diversos fueros y privilegios”, en Artola, Los Orígenes de la España Contemporánea, Madrid, 1959, II, p. 377.

${ }^{30}$ Respuestas de los obispos de Orihuela Cuenca, Urgel, de los Cabildos de Urgel, Ciudad Rodrigo, Segorbe, en Artola, Los Orígenes de la España Contemporánea, Madrid, 1959, II, p. 218, 198, 222, 236, 266 , respectivamente. En algunas de estas respuestas se insiste expresamente en la necesidad, sobre todo, de mejorar la Recopilación, como es el caso del Obispo de Albarracín o el Barón de Castellet, y en otros casos se refieren expresamente a tomar como modelo Las Partidas, "Corresponde haya un solo código y podrá adoptarse como modelo la famosa y nunca bastantemente ponderada obra de Las Partidas" (Obispo de Calahorra), o el Arzobispo de Tarragona, en Ibidem, pp. 132, 145, 144 y 130, respectivamente.

${ }^{31}$ Artola, Los Orígenes..., p. 269. En parecidos términos se expresa José Sala, quien destaca: "Yo bien se que podrán decir que una legislación uniforme para todo el reino podría perjudicar los privilegios, usos y costumbres de las provincias respectivas, que deben guardarse con toda religiosidad y cuya observancia se ha jurado casi en todas las Cortes que se han celebrado en el reino, pero esto podría evadirse, a mi parecer fácilmente, conservando a cada una los privilegios más principales, haciendo comunes de unas los que fuese más análogos con las otras, continuándose en el mismo código y en seguida de las leyes que se estableciesen a excepción de ellas...”. O el caso del abogado barcelonés Solsona, quien, 
tencia de una conciencia clara y asumida de renuncia a las instituciones particulares de cada región. Comportamiento, por otro lado, nada extraño, si tenemos en cuenta el gran arraigo social que caracteriza, al menos, a las instituciones del derecho privado.

Instituciones, cuyo mantenimiento en toda su extensión es defendido de forma expresa, aunque en número reducido, por algunos de los opinantes. Este es el caso del Ayuntamiento de Mallorca, el cual, si bien se inclina, como en la mayoría de los supuestos, a favor de la formación de un código conformado con "leyes breves, claras e inteligibles para todos", se pronuncia, a continuación, en defensa de la permanencia de la particularidad de la Isla: "Como todas estas leyes no pueden generalizarse a todas las provincias de España, es conveniente para Mallorca que subsistan las del derecho común o de los ramos, con que siempre se ha gobernado la Isla, cuyos usos y costumbres antiguas se mandaron guardar en la Real Cédula de 31 de agosto de $1736{ }^{\prime 32}$. En parecidos términos se expresan La Junta Superior de Mallorca ${ }^{33}$, José Rius $^{34}$, Franciso Javier Borrull ${ }^{35}$ o Ramón Lázaro de Dou $^{36}$, quien, de nuevo, aboga por la utilidad de un nuevo código, pero ante la dificultad de la empresa, se inclina por mejorar algunas cosas y "en seguir en lo demás la legislación que teníamos".

Del examen de las respuestas, no cabe duda de que la mayor parte de las mismas se pronuncian en un sentido favorable a la unificación, pero sin que se deje translucir una idea clara del camino a seguir para la consecución de la misma. Desde mi punto de vista, lo que se persigue, mayormente, es mejorar la técnica de la Novísima Recopilación. Dudo bastante de que en la mente de muchos de los autores de dichas respuestas pertenecientes a los territorios con legislación propia, existiera una convicción clara de renuncia a sus particularidades. Extremo que se puede deducir del análisis de algunas de estas contestaciones ( en las que lo que se aconseja es un estudio y revisión de las dichas peculiaridades. Todo ello, enmarcado en un ambiente patriótico nacionalista de lucha y defensa contra el extranjero que, no cabe duda, deformaría en cierta medida la realidad ${ }^{37}$. Aspecto,

como muy bien indica Artola, comienza por mencionar la particularidad jurídica catalana, incidiendo después en lo perjudicial que podría ser la extensión a unas provincias de las leyes hechas para otras, para terminar desarrollando el principio de uniformidad, pero y este último aspecto no lo destaca el citado autor, sustentada sobre la base de la armonización "Convendría irse leyendo todos los códigos legislativos de España y notarse las leyes que se conceptuasen oportunas...", Ibidem, II, p. 440, y I, p. 359 y II, p. 594.

${ }^{32}$ Artola, Los Origenes..., II, p. 319.

${ }^{33}$ Ibidem, p. 354.

${ }^{34}$ Idem, p. 434

${ }^{35}$ Idem, p. 508.

${ }^{36}$ Idem, p. 420.

${ }^{37}$ Realidad conformada por una diversidad jurídica que se mantenía latente en lo más profundo de los naturales de estos territorios, y que resultaba imbuida en estos momentos de un sentimiento pasional de unión contra el extranjero que la relegaba a un segundo plano, pero no por ello olvidada. Son exponente, en este sentido, las palabras de Federico de Castro, por otro lado nada sospechoso de la defensa de la diversidad, quien reconoce que "los movimientos de unificación jurídica corresponden a los mo- 
este último, ya destacado por Irigoras Alberdi, entre otros ${ }^{38}$, quien citando a su vez a Martínez Sospedra, alude al ambiente que rodeaba al proceso de consulta, contrario a la supervivencia de los ámbitos jurídicos diferenciados de los territorios forales ${ }^{39}$. Ambiente contrario, según destaco más arriba, a la diversidad representada por los derechos históricos, entendidos éstos como sistemas de determinación histórica, como cuerpos definidos, compactos y diferenciados; pero en momento alguno, al menos en mi modesto entender, hacia las particularidades que representaban las diferentes instituciones autóctonas individualizadas de estos territorios, que podrían ser atendidas para su posible integración en el nuevo sistema o en la nueva planta de los códigos $^{40}$. Cuestión, esta última, que se refleja en las propias posiciones esgrimidas en un gran número de las respuestas examinadas y, en mayor medida, en aquellas que incidían tan solo en el ámbito del derecho privado y, por tanto, no obstaculizaban al sentimiento de nación unida contra el enemigo. En este sentido es muy esclarecedora la posición del prof. Clavero quien, al analizar la contestación del Ayuntamiento de Cádiz, destaca que de la misma puede reflejarse: que si bien el proyecto codificador había podido prever la dificultad que podía entrañar la diversidad foral para su objetivo, sin embargo, en estos primeros momentos no se define frente a la misma, sino principalmente y específicamente en contra de los privilegios que se conservaban y mantenían vigentes; y que tan sólo, décadas después, una vez unificado materialmente el derecho, aunque no formalmente en los códigos, la perspectiva cambiaría, reduciéndose las motivaciones de la codificación; imaginándose impropiamente su misión histórica como la de simple unificación del derecho en el ámbito territorial del Estado, y olvidando su función más radical de superación del sistema de privilegios ${ }^{41}$. Siguiendo al mismo y de nuevo tomando como base la representación del ayuntamiento

mentos de mayor vitalidad, a la reacción frente al ataque extranjero", en Derecho civil de España, Part. Gral, t. I, Libro $1^{\circ}, 3^{\text {a }}$ ed., Madrid, 1955, p. 260.

${ }^{38}$ Ibidem, p. 260.

${ }^{39}$ Irigoras Alberdi, Derechos históricos vascos y constitucionalismo español: foralidad..., p. 50.

${ }^{40}$ Este planteamiento lo expresa el prof. Clavero a la hora de interpretar el contenido de la excepcionalidad recogida en el art. 258 de la Constitución de Cádiz, quien señala: "aunque más bien parece que tal cláusula constitucional se refería a la legislación especial de los territorios de Ultramar, y no a derechos históricos de los territorios peninsulares, los cuales, para la perspectiva constitucional, podrían ser atendidos sólo para su posible integración en el nuevo sistema o en la nueva planta de los códigos, por cuya promulgación, en cuanto a derechos históricos y en lo que aun pudiera subsistir, habrían de quedar definitivamente erradicados". También insiste, a este respecto, el citado autor, al destacar que el movimiento constitucional no podía concebir que los derechos civiles históricos subsistieran sin más, sino que la propia función constituyente debía proyectarse en materia civil en la disposición de un código que fundara, frente a la historia, su propio sistema, lo que no implicaba el que no se pudieran aprovechar elementos históricos, siempre y cuando fuesen asumidos expresamente y legitimados por la propia ley y no por la vía foral o de reconocimiento de derechos históricos (op. cit., p. 22 y 26). Ver también el mismo autor en La Idea de Código en la Ilustración Jurídica, Historia. Instituciones. Documentos (HID), 6, 1979, pp. 84 y 85.

${ }^{41}$ B. Clavero, La Idea de Código en la Ilustración ..., p. 86. 
de Cádiz, señala, que en ocasiones se planteaba la radical unificación del derecho como forma de acceder, sin términos medios, a la unidad social, pero que era la función de unidad social del derecho y no la unificación territorial la que definía el concepto codificador; situación que irá variando a lo largo del siglo, una vez que vaya desapareciendo la precaria situación social, hasta el punto que la unidad territorial se convierta en un medio aleatorio para la consecución de la social ${ }^{42}$.

En el caso de las provincias Vascongadas y Navarra, al no existir pronunciamientos de las mismas al respecto, no nos permiten conocer cuál fue su actitud frente a la unificación o defensa de su particularidad. De lo que no cabe duda, es que tales territorios se vieron inmersos en ese clima de patriotismo nacionalista que se dio en el resto del suelo español; extremo éste último que es corroborado por Mina Apat, quien destaca que en las citadas provincias, el levantamiento contra la ocupación francesa fue motivado más por la legislación liberal que se trataba de implantar, que por su condición de gobierno extranjero, aunque ello no sería óbice para que al ser extranjero el que las imponía tuviese este movimiento popular una justificación patriótica ${ }^{43}$.

A principios de 1810, la Junta Central establecida en Cádiz, desgastada por su acción de gobierno, decide disolverse y nombrar un Consejo de Regencia al que se le transfiere su autoridad sin limitación alguna. Junto al Decreto de disolución, la Junta el mismo día, 29 de enero, promulga otro Decreto relativo a la convocatoria de Cortes. La fecha del 1 de marzo, prevista inicialmente para la reunión de las mismas, no se cumplió, y hay que esperar al 24 de septiembre para la apertura de las Cortes generales y extraordinarias en la isla de León.

Convocadas las Cortes, los diputados catalanes solicitaron instrucciones a la Junta General del Principado, para el supuesto de que se suscitara en el futuro parlamento el problema de la uniformidad de la legislación y derechos. La respuesta de la Junta dice literalmente: "Que aunque desde luego deben reconocerse las ventajas políticas que resultarían de unificar la legislación y los derechos de todas las Provincias de la Monarquía para que no quede ésta después de la actual crisis hecha de un cuerpo compuesto de partes heterogéneas, con todo cuanto no pensase así la pluralidad, o cuando insuperables obstáculos se opusiesen a la realización de esta medida saludable, en tal caso Cataluña no solo debe conservar sus privilegios y fueros actuales, sino también recobrar lo que disfrutó en el tiempo en que ocupó el Trono Español la antigua Casa de Austria; puesto que los incalculables sacrificios que en defensa de la Nación está haciendo (Cataluña), la constituyen bien digna de recobrar sus prerrogativas".

\footnotetext{
${ }^{42}$ Ibidem, pp. 87 y 88.

${ }^{43} \mathrm{M}^{\mathrm{a}}$ Cruz Mina Apat, Fueros y Revolución liberal en Navarra, Madrid, 1981, pp. 69, 72 y 73. En este mismo sentido y de forma rotunda se pronuncia Arturo Campión, "Nadie se preguntaba si una medida o disposición era contrafuero, sino si parecía o era patriótica", en Discursos políticos y literarios (1 ${ }^{\mathrm{a}}$ ed. 1907), reeditado por la Gran Enciclopedia Vasca, Bilbao, 1976, pp. 27 y 265.
} 
El deseo unificador de la respuesta es expreso, ahora bien, no debemos omitir el que no se olvida tampoco de la particularidad catalana, para el caso de que éste no fuera el criterio unánime o serios inconvenientes no lograsen la consecución de la misma.

La doctrina, a la hora de analizar la citada respuesta, si bien es unánime en cuanto a los deseos unificadores que se desprenden de la misma, como no podía ser de otra forma por su propia expresividad, sin embargo encontramos diversas matizaciones al respecto. Hay autores, como es el caso de Federico de Castro, para quien dicho texto es un precedente claro de la unificación consagrada en la Constitución, otorgando a los juristas de los territorios forales la responsabilidad y las primeras iniciativas unificadoras, hasta el punto de señalar que fue de los territorios forales de donde procedió el más enérgico impulso para la redacción del Código ${ }^{44}$. Destaca, en este mismo sentido, que fue un miembro de dicha Junta, José Espiga y Gadea, quien a finales de 1810, propone la formación de comisiones para reformar unitariamente la legislación civil, criminal, de Hacienda, comercio y educación pública, quien con el apoyo posterior de otros diputados catalanes, como De Dou y Capmany, logró su organización y en última instancia la redacción del artículo 258 de la Constitución de $1812^{45}$. En un sentido diferente se pronuncia Camps y Arboix ${ }^{46}$, para quien, la conformidad prestada a los propósitos codificadores contenida en la Instrucción de la Junta General del Principado no implicaba una idea rotunda de uniformismo legislativo, y acudiendo, al igual que el autor anterior, al examen de las intervenciones de los diputados catalanes en las Cortes, llega a las siguientes conclusiones: En primer lugar, la propuesta del diputado Espiga, citada más arriba, "no entraba en la forma de legislar, ni aludía a la sistemática más procedente para realizar el propósito en relación con la diversidad de regímenes jurídicos españoles", y que por tanto no se puede considerar contradictoria con la idea de armonización, ni con la instrucción de la Junta; extremo, este último, que se corrobora en la defensa de la iniciativa que hace el propio diputado, en la que se limita a exponer, tan solo, consideraciones de tipo general sobre las conveniencias de la reforma. Acude, asimismo, en defensa de su tesis, al examen de las intervenciones de otros diputados catalanes en Cortes, como es el caso de De Dou, quien, si en un principio se alinea con la propuesta de Espiga "Ninguna cosa más grande ni más digna de desearse que un Código perfecto de legislación" "47, más tarde se expresa sobre el aspecto relativo a la concreción de cómo llevar a cabo tal reforma: ya sea sobre la base de contar con todos los Códigos de nuestra legislación o sin ellos. Extremo éste último que rechaza, destacando que para proceder según la primera fórmula propuesta (contar con todos los Códigos de nuestra

\footnotetext{
${ }^{44}$ F. de Castro y Bravo, op. cit., p. 242.

${ }^{45}$ Ibidem.

${ }^{46}$ Camps y Arboix, op. cit., pp. 55-60.

${ }^{47}$ Diario de Sesiones de las Cortes generales y extraordinarias de Cádiz, Madrid, 1870, I, p. 502.
} 
legislación), sería necesario tener presentes todos ellos (Constituciones de Cataluña, Fueros de Aragón, leyes de las Provincias Vascongadas), y al no poder disponer de los mismos en las citadas Cortes, concluye manifestando, que ante la premura del tiempo y la situación bélica que se vive, se debían mantener las leyes antiguas con limitaciones. Por lo que se refiere al diputado Aner de Esteve, éste, si bien, asimismo, está de acuerdo con la propuesta de Espiga, sin embargo considera que al ser la legislación "tan distinta en cada provincia, según sus usos y costumbres... si es para reformar la legislación general de España, es preciso que V.M. nombre una comisión para cada provincia" ${ }^{48}$.

Camps y Arboix, termina diciendo, que de los aludidos discursos se deduce claramente que sin oponerse a la idea genérica de la reforma, tampoco se olvidaban de la situación especial de los diferentes territorios españoles, como es el caso de Cataluña con derecho a que de una u otra forma su legislación fuera conservada y restablecida ${ }^{49}$.

En ejecución de la citada proposición de Espiga, aprobada conjuntamente con otra similar de Argüelles, se nombró una primera comisión dictaminadora con fecha 23 de septiembre de ese mismo año de 1811, integrada por once personas, ninguna de las cuales era diputado catalán ni de otra región jurídica que no fuera Castilla ${ }^{50}$; ausencia que se corregiría en las comisiones designadas en los años sucesivos, fruto, según Brocá, de la actividad desarrollada por De Dou en favor de la legislación catalana ${ }^{51}$

Iniciada la discusión del proyecto de Constitución el 25 de agosto de 1811, el 21 de noviembre de ese mismo año, se abrió el debate sobre el contenido del que había de ser el art. 258 de la Constitución gaditana "El Código civil y criminal y el de Comercio serán unos mismos para toda la Monarquía, sin perjuicio de las variaciones que por particulares circunstancias podrán hacer las Cortes". El debate del citado art. fue breve. Intervino el diputado americano Gordoa, quien defendió que tan solo la uniformidad de las leyes puede hacer que sean unos mismos códigos para todos los territorios de la monarquía, expresando la inutilidad de la unificación propuesta si no se aclaraba o suprimía la segunda parte del mismo, "sin perjuicio de las variaciones que por particulares circunstancias podrán hacer las Cortes", ya que al no calificarse tales variaciones, quedaba abierta la vía para justificar la introducción de particularidades contrarias a la citada unidad $^{52}$. La respuesta vino del diputado Leyva, quien

\footnotetext{
${ }^{48}$ Diario de Sesiones..., op. cit., pp. 502 y 503.

${ }^{49}$ Op. cit., p. 57.

${ }^{50}$ Diario de Sesiones..., op. cit., III, p. 1.901.

${ }^{51}$ Camps y Arboix, op. cit., p. 58.

${ }^{52}$ El citado diputado se manifiesta en los siguientes términos: "no clasificándose las variaciones, queda abierto, no ya un portillo angosto, sino una puerta anchurosa, y del tamaño que la quiera, o busque el antojo o el error obstinado de mil descontentos, que, mal hallados con esta Constitución, y guiados del espíritu de provincialismo, lejos de uniformar, pretendan, por el contrario, mantener a todo trance prácticas y costumbres, que si en otro tiempo han sido loables, no servirán en adelante más que para debilitar o romper el sagrado vínculo que debe unir a todos los españoles" (Diario de Sesiones, op. cit., III, p. 2.306).
} 
aclara, que en momento alguno ha sido intención de la comisión establecer una facultad de alterar sustancialmente los Códigos para dispensar mayores ventajas a alguna parte de la monarquía, sino que lo que se ha tratado de prever con dicha redacción es la posibilidad de que algún pueblo de la península o de Ultramar pueda requerir algún estatuto para su propio bien y que no necesiten los otros. ${ }^{53}$ Sin más intervenciones, sometido a votación, el citado artículo quedó aprobado.

Para Camps y Arboix, la aprobación del citado art. en los términos expresados, supone un reconocimiento inequívoco de la existencia de particularismos jurídicos dignos de respeto en la península y ultramar ${ }^{54}$. El citado autor considera, que tal redacción del mismo, podría deberse a la iniciativa de los representantes de las regiones de ultramar, para acallar las suspicacias de los mismos tan reiteradamente manifestadas a lo largo de las deliberaciones habidas en las Cortes, pero que sin embargo no excluía la posibilidad de que fuera una región continental la que motivara la medida de excepción. Concluye diciendo que, al margen de las motivaciones existentes, la vaguedad de la fórmula adoptada satisfizo a los diputados catalanes por cuanto daba respuesta a sus dos principales aspiraciones: sentar un principio recomendado por la Junta y no cerrar la puerta al anhelo por ésta expresado de no solo conservar los privilegios catalanes, sino también de recobrar los que disfrutó en el tiempo en que ocupó el Trono español la antigua Casa de Austria $^{55}$. Reglà, incluso llega a decir que fue la intervención de los diputados catalanes la que motivó la inclusión del segundo párrafo del art. 258 de la Constitución ${ }^{56}$.

Por lo que se refiere a los territorios Vascongados, lo primero que hay que destacar, es que los diputados procedentes de estas regiones votaron favorablemente la Constitución, con la sola excepción del diputado vizcaíno Eguía, quien se abstuvo en un primer momento de hacerlo, aunque ante el requerimiento de las Cortes, procedería a llevarlo a cabo ${ }^{57}$. También es necesario señalar, tal como destaca Irigoras Alberdi ${ }^{58}$, la irregularidad que caracterizó la elección de los mismos. Al tiempo de proceder a las elecciones para diputados, las citadas provincias se encontraban ocupadas por los franceses, por lo que la designación se realizó entre los naturales de las mismas que en ese momento se encontraban residiendo en Cádiz. Para la citada autora, la eviden-

\footnotetext{
${ }^{53}$ Ibidem.

${ }^{54}$ Camps y Arboix llega a vincular la redacción del citado art. con el propio preámbulo del texto constitucional, al señalar: "Importa notar que este precepto responde al espíritu de respeto a las antiguas leyes de los pueblos componentes de España, manifestado en el transcurso del larguísimo preámbulo o exposición de motivos de la Constitución, en el que se hacen copiosas y eruditas referencias a las modalidades de costumbres y leyes de Aragón, Cataluña, País Vasco, etc, lo cual constituye un explícito reconocimiento de su realidad" (op. cit., p. 58).

${ }^{55}$ Ibidem, pp. 59 y 60.

${ }^{56}$ Joan Reglà, Historia de Catalunya, Barcelona, 1972, II, cap. VII, pp. 207 y 211.

${ }^{57}$ J.J. Sánchez Arreseigor, El primer constitucionalismo vasco, en www.historiacontemporanea. ehu.es/s0021-con/eu/.../35_15.pdf, p. 768.

${ }^{58}$ Irigoras Alberdi, op. cit., p. 59.
} 
cia de la existencia de defectos en la elección de diputados, podría explicar la pasividad entre tales diputados a la hora de plantear algún tipo de declaración tendente a la conservación de sus particulares sistemas jurídicos ${ }^{59}$. Concluye la mencionada autora, que "podemos suponer" que en el caso de que dicha elección de diputados se hubiera realizado por la instituciones correspondientes y de acuerdo con la legalidad foral, no se habrían admitido sin oposición alguna todas aquellas nuevas medidas constitucionales que menguaban los sistemas forales; aunque también reconoce, como lo hacían otros autores con respecto a la respuestas catalanas, las circunstancias especiales que se daban como consecuencia de la situación bélica que se vivía y que, por lo tanto, no resultaba muy patriótico ni adecuado contrariar las ideas reflejadas en la Constitución en un asunto como el mantenimiento de los Fueros. Citando al representante guipuzcoano Zumalacárregui, señala: "lo importante en estos momentos era ganar la guerra y no un planteamiento de la cuestión foral en las Cortes" ${ }^{60}$

Al margen de la consideración que hagamos acerca de la actitud de los diputados catalanes y la designación de diputados de los territorios vascongados, es un hecho que la Constitución de 1812 quedó aprobada y refrendada por los mismos. Como también hemos señalado anteriormente, la unidad de códigos quedaba reflejada en los términos antes expuestos, en los que se admitía en su segundo párrafo "sin perjuicio de las variaciones que por particulares circunstancias podrán hacer las Cortes". Extremo este último que ha sido interpretado desde distintos puntos de vista. Existe una corriente que considera que el citado párrafo fue incorporado al texto constitucional, a iniciativa de los diputados catalanes que lograron con ello salvar la vigencia del Derecho catalán ${ }^{61}$; mientras que otros, entre los que se encuentra de forma muy destacada el prof. Clavero, mantienen, que dicha cláusula se refería a la legislación especial de los territorios de Ultramar y no a los derechos históricos de los territorios peninsulares; los cuales, para la perspectiva constitucional, podrían ser atendidos solo para su posible integración en el nuevo sistema o en la nueva planta de los códigos, por cuya promulgación, en cuanto derechos históricos y en lo que pudieran subsistir, habrían de quedar definitivamente erradicados ${ }^{62}$. Aceptando la posibilidad de que la citada coletilla estu-

${ }^{59}$ Ibidem, p. 60. La citada autora alude a un incidente que se produjo en torno al diputado por Álava, Manuel de Aróstegui, lo que denotaría la calidad de la representación de los diputados a Cortes.

${ }^{60}$ Irigoras Alberdi, op. cit., p. 61.

${ }^{61}$ Reglà, op cit., II, p. 211.

${ }^{62}$ Este planteamiento lo expresa el prof. Clavero a la hora de interpretar el contenido de la excepcionalidad recogida en el art. 258 de la Constitución de Cádiz, quien señala: "aunque más bien parece que tal cláusula constitucional se refería a la legislación especial de los territorios de Ultramar, y no a derechos históricos de los territorios peninsulares, los cuales, para la perspectiva constitucional, podrían ser atendidos sólo para su posible integración en el nuevo sistema o en la nueva planta de los códigos, por cuya promulgación, en cuanto a derechos históricos y en lo que aun pudiera subsistir, habrían de quedar definitivamente erradicados", También insiste a este respecto, el citado autor, al destacar que el movimiento constitucional no podía concebir que los derechos civiles históricos subsistieran sin más, sino que la propia función constituyente debía proyectarse en materia civil en la disposición de un código que fun- 
viera vinculada con las provincias de América y Asia, Roca y Trias, añade, sin embargo, que la incorporación de dicha expresión en constituciones posteriores no se refirió ya a los problemas a que parece responder su inclusión en la de $1812^{63}$. Redundando en esta idea se manifiesta también Camps y Arboix, quien resalta, que si bien es posible que dicha previsión fuera contemplada a iniciativa de los representantes de las regiones de ultramar y "para acallar las suspicacias de los mismos, tan reiteradamente manifestadas a lo largo de las deliberaciones de aquellas Cortes hasta constituir una verdadera pesadilla", pero no por ello es menos cierto que no se excluía la posibilidad de que fuera una región continental la que motivara la medida de excepción, como es el caso de Cataluña, y que esta sería la razón de que los diputados catalanes aceptaran con satisfacción la vaguedad de la fórmula ${ }^{64}$. Por último, el prof. Gibert, añade que la reserva contenida en el citado art. constitucional situaba desde el principio la Codificación española en un plano realista ${ }^{65}$.

De las posturas existentes relacionadas con el segundo párrafo del art. 258 de la Constitución, cabe deducir el planteamiento siguiente: De los datos con los que contamos, es difícil extraer una idea clara y definitiva de las intenciones de los redactores del texto constitucional al recoger el mismo. Es posible, que pudiera responder a los requerimientos de los diputados de las provincias de ultramar, pero también es cierto, como señalaba Roca y Trias, que dicho párrafo se volvería a recoger en constituciones promulgadas en la segunda mitad del siglo XIX, sin que parezca que en estos momentos persiguiera objetivos similares Por otro lado, resulta más complicado aún demostrar la posible relación del citado texto con la intervención de los diputados catalanes. Ahora bien, de lo que no cabe ninguna duda es que su inclusión en el texto constitucional abrió la posibilidad de que fuera cualquier región, ya fuera continental o de ultramar, la que motivara la medida de excepción, como muy bien señalaba el diputado Gordoa en su intervención en las Cortes "y si no se suprime o aclara la segunda, que dice sin perjuicio de las variaciones que por particulares circunstancias podrán hacer las Cortes... estas variaciones podrán ser o no sustanciales, y por lo mismo aventuraré el efecto de este y otros muchos artículos de la Constitución, ...no clasificándose las variaciones, queda abierto, no ya un portillo angosto, sino una puerta anchurosa, y del tamaño que la quiera, o busque el antojo o el antojo o el error

dara, frente a la historia, su propio sistema, lo que no implicaba el que no se pudiera aprovechar elementos históricos, siempre y cuando fuesen asumidos expresamente y legitimados por la propia ley y no por la vía foral o de reconocimiento de derechos históricos (B. Clavero, El Código y el Fuero. De la cuestión regional en la España contemporánea, Madrid, 1982, pp. 21 y 22). Ver también el mismo autor en La Idea de Código en la Ilustración Jurídica, Historia, Instituciones, Documentos (HID), 6, 1979, pp. 84 y 85.

${ }^{63}$ E. Roca y Trias, El Derecho Civil Catalán en la Constitución de 1978, Estudio comparativo del tratamiento de los derechos civiles españoles en las distintas constituciones y en la vigente, en Revista Jurídica de Cataluña, 1, 1979, p. 9.

${ }^{64}$ Camps y Arboix, op. cit., p. 59.

${ }^{65}$ Gibert, op. cit., p. 909. 
obstinado de mil descontentos, que, mal hallados con esta Constitución, y guiados del espíritu de provincialismo, lejos de uniformar, pretendan, por el contrario, mantener a todo trance prácticas y costumbres... ${ }^{66}$. Esta última posibilidad de dejar una puerta abierta aunque ambigua, podría ser la contemplada y defendida por Gibert que, como antes mencionábamos, considera que la citada reserva no hace sino que contemplar la codificación desde una perspectiva realista. En parecidos términos se pronuncia Álvarez de Morales, quien señala: "Con lo que el propio texto constitucional abría las puertas a una variedad para que una excesiva uniformidad no impidiera el ideal codificador" 67 .

Fuera de las Cortes también se dejaron oír otras voces. Este es el caso de los vascos Calvo Rozas, conocido liberal, Pablo de Jérica Corta, quien defendería y difundiría las nuevas ideas a través de la prensa, o Valentín Foronda, perteneciente a la vanguardia intelectual, quien consideraba anacrónicos los Fueros, pero que, sin embargo, hace un retrato sobre la realidad de los mismos en Guipúzcoa altamente significativa "Esta provincia está llena de fueros y de privilegios, y sus naturales los estiman tanto, que aunque se les brinde con muchas ventajas, no las admitirán como llegue a rozar con ellos ... Pero esto nada importa con que se llamen fueros, cuya voz es tan bonita y halagüeña para sus oídos que se arroban al pronunciarla....”. En el bando contrario, Trifón Ortiz de Pinedo, abiertamente se declara contrario a la Constitución ${ }^{68}$.

Promulgada la Constitución, mediante decreto de 23 de mayo se procedió a convocar Cortes ordinarias, estableciéndose como condición previa, la jura de la misma. La Constitución sería jurada en la totalidad de los territorios peninsulares, incluidos aquellos en lo que existía particularidad jurídica ${ }^{69}$.

El hecho de la aceptación y jura de la Constitución parece indicar una normalidad, en cuanto a la asunción de la misma. Extremo que ha llevado a muchos autores a pensar en la inexistencia de cualquier tipo de oposición a todo aquello que implicaba su contenido, y por tanto, a la unificación jurídica. Está muy extendida la idea de que las reivindicaciones foralistas no se inician hasta la década de los 30 en las provincias Vascongadas y Navarra, e incluso más tardíamente en el caso de Cataluña. En este sentido Juan Pablo Fusi, destaca: “que ni la aprobación de la Constitución de 1812 ni su posterior restablecimiento en 1820-23 -que en ambos casos supuso la abolición de los Fueros- produjeron reacción foralista alguna de importancia ni en las provincias vascas ni en Navarra, hecho que evidentemente sorprende a la vista de lo ocurrido

\footnotetext{
${ }^{66}$ Diario de Sesiones, op. cit., III, p. 2.306

${ }^{67}$ A. Álvarez de Morales, Historia del Derecho y de las Instituciones españolas, Granada, 2002, p. 336.

${ }^{68}$ Sánchez Arreseigor, op. cit., p. 768. Con respecto a las palabras de Foronda, en A. Elorza, La ideología liberal en la Ilustración española, Madrid, 1970, p. 125.

${ }^{69}$ Con la sola excepción de Vizcaya, cuyas Juntas Generales no la llegaron a jurar, aunque dieron orden de que fuera jurada por todos los pueblos del Señorío. El gobierno ordenó que la jurasen también las Juntas Generales, como tales, pero la orden no se cumplió al ser reconquistada Bilbao por los franceses (Sánchez Arreseigor, op. cit., p. 776).
} 
posteriormente" ". Es cierto que si entendemos por "fuerismo", tal y como señala el mismo autor, "un planteamiento político nítidamente articulado que, en razón del pasado foral, demanda un tratamiento constitucional distinto para las provincias vascas y Navarra"71, no cabe la menor duda que no se plantea en estos momentos y que será de más tardía aparición ${ }^{72}$, pero, sin embargo, ello no significa que no hubiera existido anteriormente un desconocimiento de lo que representaban exactamente los principios constitucionales y un sentimiento real de rechazo a la pérdida de sus peculiaridades jurídicas, mayor en el caso de las Provincias Vascas y Navarra al afectar a su propia configuración política, que constituiría el origen de lo que a partir de los años 30 se convierte en un movimiento articulado y compacto.

Considero que los acontecimientos que se produjeron una vez promulgada la Constitución, mayormente en el plano teórico, al tratarse de un texto que prácticamente no se aplicó, nos pueden ayudar a comprender mejor el ambiente que caracterizó el momento. Ambiente en el que se observa un mayor apego a las articularidades existentes del que se había venido defendiendo y un gran desconocimiento, en muchos casos, de lo que realmente implicaba el planteamiento liberal. Extremos que son recogidos por Martínez Sospedra, al señalar que en las mentes de los diputados no sólo no permanecía el deseo de erradicar las instituciones político-administrativas forales, sino que parece vislumbrarse un afán de trasladar al resto de provincias una organización que se había mostrado eficaz en los territorios forales ${ }^{73}$.

Si bien, como decíamos antes, la Constitución fue jurada y aceptada por todos ${ }^{74}$, sin embargo tal aceptación no estuvo exenta de una serie de incidentes, al menos en los territorios vascongados.

En primer lugar hay que destacar que el 16 de agosto de 1812, el general Mendizábal lanzo un manifiesto a los vascos, un tanto confuso, posiblemente con el objetivo de allanar el camino a la aceptación de la Constitución por las Juntas Generales, en donde proclamaba: "Vizcaínos, Guipuzcoanos y Alaveses, vosotros habéis prestado el modelo. Vuestras leyes han sido el oráculo de la prosperidad nacional"75. La aceptación fue sin reservas en Álava ${ }^{76}$, aunque también es verdad que dicho órgano se en-

${ }^{70}$ J.P. Fusi Aizpurua, Constitución y Fueros: Análisis político de un debate secular, en Jornadas de estudios sobre la Actualización de los Derechos Históricos Vascos, San Sebastián, julio 1985, Ed. en Bilbao, 1986, p. 225.

${ }^{71}$ Ibidem.

${ }^{72}$ En este sentido se pronuncia también A. Cajal Valero, quien señala "estamos todavía muy lejos del fuerismo desarrollado, es decir, del elaborado, consciente y maduro liberalismo fuerista desplegado doctrinal y políticamente en la transición que siguió a la muerte de Fernando VII, de forma paralela a la primera guerra carlista" (Paz y Fueros. El Conde de Villafuertes. Guipúzcoa entre la Constitución de Cádiz y el Convenio de Vergara (1813-1839), Madrid, 2002, p. 31).

${ }^{73}$ Citado por Irigoras Alberdi, op. cit., p. 57.

${ }^{74}$ Es necesario resaltar la salvedad en el caso de Vizcaya, referida en la nota 59.

${ }^{75}$ Sánchez Arreseigor, op. cit., p. 770.

${ }^{76}$ Arciniega, 25 de noviembre de 1812. 
contraba presidido por el propio Mendizábal, lo que para Irigoras Alberdi, hubiera podido influir en el ánimo de los representantes alaveses ${ }^{77}$. En el caso de las Juntas Generales de Guipúzcoa, el acto de la jura ${ }^{78}$ no suscitó tampoco problemas, aunque el acta de juramento estaba redactada de forma ambigua y condicional, "este código nacional y la Constitución nativa y original de Guipúzcoa tienen una íntima analogía y se conforman esencialmente" 79 , términos que no gustaron al Ministerio de la Gobernación, pero optaron por dejarlo estar ${ }^{80}$. Serían las Juntas Generales de Vizcaya las que plantearían problemas más serios al acto de aceptación y jura de la Constitución. Convocadas las Juntas ${ }^{81}$, leído completo el texto de la Constitución, se procedió a su aceptación o no. Se inició el debate entre aquellos que defendían la Constitución sin limitación alguna, y aquellos otros que consideraban la necesidad de analizar la cuestión antes de abandonar los Fueros del señorío. Ante los pronunciamientos opuestos, surgió una tercera vía, hábil y conciliadora, que defendía la posición intermedia de aceptar la Constitución pero conservando los Fueros en todo lo posible. La discusión fue elevándose de tono, requiriendo la intervención de Mendizábal para poner orden. La polémica se cerraría en falso, e invocando la proclama de Mendizábal a todos los vascos, antes referida, se llegó a la conclusión de que jurar la Constitución era jurar los Fueros, y se decidió nombrar una comisión para que hiciera gestiones ante la Regencia, acerca de si era posible conciliar la constitución vizcaína y la española o era necesario renunciar a la primera. El gobierno envió órdenes tajantes para que se publicara y jurara la Constitución sin dilación, restricción ni modificación alguna. Las Juntas Generales no llegaron a jurar la Constitución de Cádiz, pero ordenaron que fuera jurada en todos los pueblos del Señorío. El gobierno, de nuevo, insistió en la necesidad de la jura por parte de las Juntas Generales, orden que no se cumplió al ser reconquistada Bilbao por los franceses ${ }^{82}$.

De las propuestas provenientes de las Juntas de Vizcaya y Guipúzcoa, como se ha señalado, se puede deducir una defensa de sus instituciones forales, que enlazaría con la corriente de opinión liberal vasca conceptuada por Javier Pérez Núñez como: "la ilusión de la identidad entre la Constitución y los Fueros", que comienza a tomar

\footnotetext{
${ }^{77}$ Irigoras Alberdi, op. cit., p. 63.

${ }^{78}$ El 28 de julio de 1813 se reunieron en Deva las Juntas Generales de Guipúzcoa. El 16 de agosto el diputado general conde de Villafuertes comunicaba a la Regencia que Guipúzcoa había jurado la Constitución (Sánchez Arreseigor, op. cit., p. 776).

${ }^{79}$ Rubio Pobles, Liberalismo y fuerismo en el País Vasco (1808-1876), Victoria-Gasteiz, 2002, p. 23.

${ }^{80}$ Cajal Valero, Paz y Fueros. El Conde de Villafuertes. Guipúzcoa entre la Constitución de Cádiz y el Convenio de Vergara (1813-1839), Madrid, 2002, p. 34.

${ }^{81}$ Liberado Bilbao, las Juntas Generales de Vizcaya se reunieron los días 16-28 de octubre de 1812, presididas por el general Mendizábal, única vez en la historia que un guipuzcoano ejerció la presidencia efectiva de las Juntas Generales de Vizcaya, aspecto que, sin embargo, no planteó objeción alguna (J. Aguirreazkuenaga, Las dinámicas de la revolución liberal en Euskal Herria, en Historia de Euskal Herria. Historia general de los vascos, San Sebastián, Lur, 2004, IV, p. 160).

${ }^{82}$ Sánchez Arreseigor, op. cit., pp. 775 y 776.
} 
cuerpo tras la aprobación de la Constitución de 1812, y que considera la innecesaria aplicación en estos territorios del texto constitucional, al disponer los mismos de un sistema propio, en todo caso extensible al resto de las provincias ${ }^{83}$.

Posteriormente al acto de aceptación en el ámbito de las Juntas, se procedió a cumplimentar tal requisito por parte de los ayuntamientos, donde fue jurado sin oposición el texto constitucional. Algunos autores ${ }^{84}$ estiman que dicha aprobación pudo verse influida por las manipulaciones ejercidas por el gobierno constitucional, el cual encargó su presentación y lectura a personas de cierto prestigio, como es el caso de Mendizábal, quienes con su presencia y discurso podían incidir en el resultado final. Extremo que Fusi ${ }^{85}$, sin negarlo categóricamente, sí lo minimiza, destacando la posible escasa capacidad efectiva de unas Cortes, refugiadas en la ciudad de Cádiz y rodeadas por las tropas francesas.

El discurso historicista del preámbulo de la Constitución gaditana utilizado por Mendizábal para facilitar la transición al nuevo sistema, según otros muchos autores ${ }^{86}$, no lograría los resultados esperados, sino que por el contrario, constituirá el arranque de la reinterpretación y mitificación de los Fueros. Cuestión, que terminará brindando el apoyo ideológico y doctrinal necesario para su encuadre constitucional posterior, en lugar de conseguir la superación de la foralidad, como se perseguía.

La Constitución sería asimismo aceptada, como no podía ser de otra forma, por los diputados elegidos para las Cortes Ordinarias, quienes, según destaca José María Mutiloa, creían que las circunstancias del momento imponían una óptica nacional ${ }^{87}$.

De cualquier manera, el acatamiento de la Constitución por parte de las Juntas y ayuntamientos, no impidió que su desarrollo y aplicación en los territorios forales se viera limitado en muchos aspectos. Las órdenes de la Regencia eran cumplidas en el papel pero desvirtuadas en la práctica ${ }^{88}$, o en otras ocasiones eran desatendidas; hasta el punto que, al menos, en un primer momento, las diputaciones forales continuaron funcionando como tales, asumiendo las funciones y designación de las constitucionales diputaciones provinciales; muestra clara de las reticencias existentes a instaurar las instituciones de acuerdo con el modelo que había quedado establecido en el texto de $1812^{89}$. No debemos obviar, por otro lado, la actitud ambigua manifestada en mu-

${ }^{83}$ Irigoras Alberdi, op. cit., p. 63. En parecidos términos se pronuncia Rubio Pobes, quien considera que ya en 1812-13 se prefigura uno de los futuros contenidos del fuerismo, la idea de la perfecta integración del orden foral en la organización constitucional del Estado en razón a la existencia de una esencia liberal común (Revolución y tradición ..., p. 136).

${ }^{84}$ J.A. Zabala, en Jornadas de estudios sobre la Actualización de los Derechos Históricos Vascos, San Sebastián, Julio 1985, Ed. en Bilbao, 1986. Debate de martes 16 de julio de 1985, p. 351.

${ }^{85}$ J.P. Fusi, en op. cit. Debate de martes 16 de julio de 1985, p. 354.

${ }^{86}$ A. Carvajal Valero, op. cit., p. 32. M.C. Mina Apat, op. cit., p. 65.

87 J.M. Mutiloa, Guipúzcoa en el siglo XIX, San Sebastián, 1982, p. 222.

${ }^{88}$ Rubio Pobes, Revolución y tradición..., p. 138.

${ }^{89}$ En este sentido cabe destacar siguiendo a Irigoras Alberdi, A., que el proceso seguido para las primeras elecciones provinciales celebras de septiembre de 1813 en las tres provincias vascongadas estaría pla- 
chos casos por las mismas, atendiendo algunas de las nuevas disposiciones y oponiéndose a aquellas que no les resultaban beneficiosas ${ }^{90}$.

Por parte de la Regencia, también existió una predisposición para evitar una ruptura radical con el orden existente, al objeto de facilitar la transición e instauración del nuevo régimen. Una de las primeras medidas adoptadas por ésta, sería la de designar como jefes políticos a las mismas personas que ya eran diputados generales. Estos deseos de la Regencia no se vieron correspondidos por parte de los designados. Este es el caso de Letona, primer jefe político de Vizcaya, quien haría todo lo posible para boicotear el sistema desde dentro ${ }^{11}$, o el propio Villafuertes, que, como jefe político de Guipúzcoa, trató de compatibilizar Fueros y Constitución ${ }^{92}$.

Esta actitud de las autoridades de los territorios forales ${ }^{93}$ se debió, tal y como destaca Rubio Pobes, a la ingenuidad y desconocimiento de lo que el liberalismo, como forma de gobierno, suponía ${ }^{94}$. Por tanto no nos debe extrañar, según sigue apuntando la citada autora, "que en esta época comulgaran en las mismas posiciones políticas convencidos liberales... y futuros destacados fueristas" 95 .

Como señala Sánchez Arreseigor ${ }^{96}$, si bien el número de liberales vascos en 1813 era reducido, la prensa se encargó de difundir las nuevas ideas. Muestra de ello fue el papel jugado por El Bascongado, cuyo objetivo, proclamado abiertamente, era "inspirar amor a la Constitución". Las autoridades forales, por su parte, respondieron intentando ejercer su control sobre el mismo, forzándole a incluir artículos a favor de los fueros ${ }^{97}$.

En lo que se refiere a Navarra, jurada la Constitución ${ }^{98}$, se llevaron a cabo las elecciones a Cortes ordinarias bajo el signo de la normalidad ${ }^{99}$. El hecho de participar en las Cortes de la Nación, no supuso, según destaca M Cruz Mina, la renuncia total al

gado de irregularidades, lo que derivó en que las diputaciones provinciales continuaran dominadas por miembros de la oligarquía rural, defensores acérrimos de los fueros y sin una idea clara del alcance que podían suponer las novedades constitucionales en la regresión de los sistemas forales Asimismo, señala que estas mismas irregularidades alcanzaron el ámbito local, ocupados por personalidades provenientes de la oligarquía tradicional vasca, con la sola excepción de Bilbao y San Sebastián (op. cit., p. 64).

${ }^{90}$ Irigoras Alberdi, op. cit., p. 63.

${ }^{91}$ Sánchez Arreseigor, op. cit., p. 777.

${ }^{92}$ Ibidem, p. 778.

${ }^{93}$ Las autoridades vascas, como declaró expresamente la diputación guipuzcoana, no estaban dispuestas a consentir jamás la oposición a los fueros (Rubio Pobes, Revolución y tradición..., p. 139).

${ }^{94}$ En parecidos términos se pronuncia Cajal Valero, op. cit., 32.

${ }^{95}$ Ibidem, p. 139. En este mismo sentido también se pronuncia Irigoras Alberdi, op. cit., p. 64.

${ }^{96}$ Sánchez Arreseigor, op. cit., pp.782 y 783.

${ }^{97}$ En Guipúzcoa, surgió también un periódico de gran éxito y difusión La Papeleta de Oyarzun, y en el caso de Álava aparecería El Correo de Vitoria, cuyo colaborador Pablo de Jérica, sería un gran defensor del liberalismo (Ibidem, p. 782).

${ }^{98}$ Estella, capital interina de Navarra, por haber sido su territorio uno de los primeros liberados, fue la primera que juró la Constitución, el 31 de julio de 1812.

${ }^{99}$ Aspecto, según $\mathrm{M}^{\mathrm{a}}$ Cruz Mina Apat, silenciado por los historiadores fueristas, en op. cit., p. 67. 
orden institucional propio ${ }^{100}$. Es más, la misma autora alude a un memorial presentado en la sesión secreta de las Cortes de 20 de agosto de 1813, por cuatro antiguos diputados del reino, en el que solicitaban licencia para congregar las Cortes de Navarra con objeto de publicar la Constitución, al igual que las provincias Vascongadas habían celebrado por juzgarse incompatibles dos cuerpos legislativos en un mismo Estado. Memorial que lleva a la citada autora a plantearse las siguientes cuestiones: "¿Se trataba de sancionar foralmente la nueva legalidad para evitar reclamaciones futuras? ¿o se trataba de hacer compatibles ambas constituciones manteniendo alguna forma de poder local con que frenar las medidas excesivamente democráticas de los legisladores gaditanos? ${ }^{101}$.

Por último, con respecto a los otros territorios con derechos particulares, como es el caso de Cataluña, Aragón o Baleares, es cierto que no encontramos respuesta por parte de los mismos a la aceptación y jura de la Constitución, que fue asumida sin contratiempos, a excepción de algunos protagonizados por miembros del clero por motivos que incidían estrictamente en la defensa de sus intereses, ya fuesen éstos de carácter económico, o de otra índole, como era la supresión de la Inquisición ${ }^{102}$.

Esta falta de respuesta por tales territorios es fácilmente comprensible, ya que durante este periodo, al margen del contenido del art. 258 de la Constitución, sobre el que ya se habían pronunciado en su momento, no se adoptaron medidas que incidieran en su estatus jurídico propio.

La brevedad del periodo constitucional, junto a la resistencia ofrecida por las provincias Vascongadas a la aplicación de las medidas aprobadas, dieron como resultado una práctica falta de efectividad en cuanto al desarrollo del mismo.

La vuelta de Fernando VII en 1814 y la subsiguiente reinstauración del Antiguo Régimen no acallaron las reivindicaciones foralistas, aunque, en este caso, por razones diferentes. No se trataba ya tanto de la desaparición de los sistemas forales en aras de la unificación de acuerdo con los principios constitucionales, como de las temidas reformas que proyectaba llevar a cabo el monarca absoluto, con el propósito

${ }^{100}$ La citada autora cita, del mensaje de la Primera Diputación Provincial que juró la Constitución en Estella a los diputados en Cortes, las siguientes palabras: "Claro es que una de nuestras primeras y más graves atenciones inseparables de lo que debemos a la patria, fue desde el principio y será constantemente siempre la de examinar si hay medio eficaz con que se les reintegre en su antigua y nobilísima constitución de que llora verse despojada sin ser oída y sin los precisos conocimientos. Pero creemos que no es materia en que conviene mover hasta el momento oportuno, esperando que el tiempo y la variación de las cosas nos lo ofrezcan" (op. cit., p. 68).

${ }^{101}$ Ibidem, p. 68.

${ }^{102}$ La Instrucción de los Ilustrísimos señores obispos de Lérida, Tortosa, Barcelona, Urgel, Teruel y Pamplona, fechada el 12 de diciembre de 1812, tenía como objetivo "defender el absolutismo, realizar una apología del clero y los religiosos, criticar la intervención del Estado en la disciplina externa de la Iglesia, justificar sus bienes y sus riquezas, además de calificar a los liberales gaditanos de ser tan irreligiosos como los revolucionarios franceses" (A. Sánchez i Carcelén, Eclesiásticos catalanes y las Cortes de Cádiz, Anuario de Historia de la Iglesia, 19, 2010, p. 139). 
de afianzar su poder en aquellas regiones. La dilación en la jura de los fueros por parte del monarca avivaron las inquietudes de estos territorios, hasta el punto que el comisionado en Cortes por Guipúzcoa, ya en marzo de 1814, insinuaba la necesidad de formar un frente común de las mismas, al que se invitaba a integrarse a Navarra, para adoptar una actitud común frente a los posibles ataques que pudieran estar pergeñándose por parte del gobierno central ${ }^{103}$.

Jurados los Fueros por Fernando VII, y ante las acuciantes necesidades de la Hacienda estatal, éste inició una campaña ideológica que justificara las reformas que se proponía desarrollar en este sentido. Campaña, sustentada en los principios de la primacía real negando para ello el carácter pactista de los Fueros, a la que no tardaron en responder los territorios forales con la suya propia que desmontara la anterior. De cualquier manera, cabe concluir, como afirma Rubio Pobes ${ }^{104}$, que en las intenciones del monarca subyacía la firme voluntad de afianzar su poder, pero nunca una vocación centralista y unificadora como la que caracterizará al futuro Estado liberal.

En el caso de Cataluña, aunque la situación era muy diferente que la de las provincias Vascongadas y Navarra, también se van a producir una serie de acontecimientos que permiten visualizar el arraigo existente con respecto a sus particularidades jurídicas. A raíz de la consulta formulada por el alcalde corregidor de Figueras a la Audiencia de Barcelona en el año 1815, relativa al derecho supletorio del principado, El Consejo de Castilla ${ }^{105}$ acordó oír al ministerio público e instruir expediente oyendo, a su vez, al inexistente Colegio de Abogados de Barcelona, por lo que dicho trámite fue suplido solicitando el dictamen de cuatro letrados ${ }^{106}$. Éstos, después de tres años de estudios y consultas, redactaron un extenso informe en el que destacando el valor de las costumbres, se expresan en los siguientes términos: "Como letrados españoles miran los infrascritos la autoridad de las leyes Reales... pero como abogados catalanes e inmediatos observadores de la necesidad y utilidad de guardarse los usos y costumbres con que largos siglos se ha vivido en el Principado deben recordar a la sabiduría y atención de V.E., sin faltar al respeto debido a las leyes Reales, el trastorno que causaría a las familias de esta provincia su indistinta y aplicación a todos los casos y materias" 107 .

De los particulares recogidos en el informe anteriormente citado podemos deducir que, al margen de estar motivado por un tema muy específico, como es el de la necesidad de definir qué derecho actúa como supletorio en el Principado, los plantea-

\footnotetext{
${ }^{103}$ Rubio Pobes, Revolución y tradición ..., p. 140.

${ }^{104}$ Ibidem, p. 145.

${ }^{105} \mathrm{Al}$ que se la había remitido el monarca, al acordar la citada Audiencia elevársela al mismo.

${ }^{106}$ Los Letrados designados fueron: Agustín Tamaro, Francisco Tomás Ros, Juan de Balle y Juan Francisco Basora.

${ }^{107}$ Camps y Arboix, op. cit., pp. 71-73. También en J. Vallet de Goytisolo, Cotejo con la Escuela Histórica de Savigny. Tercera Parte: El Derecho Popular y la Costumbre en el Derecho de Cataluña y según los autores de la escuela jurídica catalana moderna, en Revista Jurídica de Cataluña, 1 (enero-marzo), 1980, p. 23.
} 
mientos esgrimidos en el mismo escapan de una mera valoración técnico-jurídica, para adentrarse en una defensa de su particularidad normativa en su conjunto, y todo ello va acontecer en un momento en el cual, como muy bien ha destacado Vallet de Goytisolo, la influencia de la escuela histórica difícilmente podría haber influido en los planteamientos de sus autores "subrayemos que estos abogados -sin probabilidades serias de haber conocido el manifiesto fundacional de la escuela histórica-, escribían que estaba afianzada la nacionalidad de estas costumbres y prácticas, conservada de siglos hasta nuestros días" 108 .

Muy diferente resultaría el informe del fiscal quien, después de rebatir algunos de los puntos esgrimidos en el escrito anterior, se limitaba a considerar que la vigencia del sistema constitucional iniciado en 1812 dejaba sin objeto la cuestión debatida y que, por tanto, procedía o archivar el expediente o en su caso adoptar aquella providencia que se considerare adecuada atendidas las circunstancias ${ }^{109}$.

Al quedar el asunto sin resolver, resurgiría en el año 1822, con ocasión del informe solicitado, de nuevo, por la Audiencia de Barcelona a cuatro letrados barceloneses, entre los que se encontraba Lázaro De Dou; a quienes se les requería para que propusieran las medidas que consideraban adecuadas para asegurar la pacificación del Principado. En esta ocasión, el fiscal propugnaba la reforma de las leyes civiles y procesales con el fin de acabar con la incertidumbre existente en torno al derecho supletorio, y a la inseguridad jurídica que ello conllevaba ${ }^{110}$. Al alegato del fiscal no tardaría en responderle, De Dou, quien pretendía poner fin a la amenaza que orbitaba sobre el derecho catalán, máxime en un momento en que ya había comenzado a actuar la comisión nombrada por las Cortes de 1820 para redactar los códigos ${ }^{111}$. La memoria redactada por el citado autor dirigida al monarca, y remitida por este último al Consejo de Castilla, criticaba lo que para él eran débiles argumentos fiscales, oponiéndose al cambio de costumbres y prácticas de los catalanes, y solicita del monarca que facilite y premie la redacción de un compendio del derecho del que gozan los habitantes de Cataluña, teniendo en consideración el Decreto de Nueva Planta ${ }^{112}$.

\footnotetext{
${ }^{108}$ Vallet de Goytisolo, op. cit., p. 23.

${ }^{109}$ Camps y Arboix, op. cit., p. 74.

${ }^{110}$ Camps y Arboix transcribe los siguientes extremos del citado informe: "ya por defecto de las leyes y constituciones de Cataluña, ya por estilos inveterados, ya por difícil que era el que los Fiscales que venían de otras provincias, y aun los naturales de ésta, siguiesen un método uniforme y constante en la sustanciación de las causas, cuando al particular de aquí no se enseñaba en ninguna Universidad o Academia pública, sino sólo se aprendía con el estudio de los libros de este país poco conocidos fuera de él, y con la práctica de sus Tribunales y Juzgados", a los que considera de una gran pobreza dialéctica que muestra el desamparo en el que vive el derecho catalán, de hondas raíces populares, cuya enseñanza se veía obstaculizada (Ibidem, p. 75).

${ }^{111}$ Ver M. Peset Reig, La primera codificación liberal en España (1808-1823), en Revista Crítica de Derecho Inmobiliario, 488, 1972, pp. 125-157.

${ }^{112}$ Camps y Arboix, asimismo, recoge parte de escrito de De Dou, que transcribo a continuación: "siendo corto el número de Jueces que han de venir a estas provincias respecto a la población de sus súbditos, y por otra parte cada uno de ellos autorizado para administrar justicia con una larga carrera y título del
} 
El Consejo de Castilla, en consideración a la memoria de De Dou, ordenó a la Audiencia de Barcelona que abriera y tramitara expediente al efecto. La citada institución abrió una encuesta en la que deberían informar el ministerio fiscal, el Ayuntamiento de Barcelona, así como los de las cabezas de los partidos judiciales de Cataluña. El resultado de la misma en el ámbito municipal, según señala Camps y Arboix, arrojó una mayoría notable a favor del mantenimiento del derecho supletorio clásico, considerando aquella legalidad consustancial a la comunidad ${ }^{113}$. Prácticamente en idénticos términos se pronuncia el fiscal, quien denunciando las corruptelas existentes en los tribunales catalanes, se inclina por el mantenimiento del ordenamiento legal catalán a este efecto "para evitar arbitrariedades en los juicios es necesario declarar cual es el derecho supletorio con arreglo a la constitución municipal confirmada en la Nueva Planta en cuanto no se oponga a ésta ni a las leyes, reales decretos y órdenes posteriores, ni a las regalías, y en cuanto sea posible a los usos y costumbres actuales, generalmente recibidos en el Principado... ${ }^{114}$. De los nueve magistrados de la Audiencia, cuatro y el Regente se adhirieron al parecer del fiscal, uno de ellos se pronunciaba a favor de la necesidad de llevar a cabo un compendio del derecho particular del territorio, y tres de ellos formularon voto particular ${ }^{115}$.

En términos de Camps y Arboix, el conflicto terminó no por crisis sino por lisis, lo que motivaría que el poder ejecutivo diera por archivado el expediente ${ }^{116}$.

La situación en Navarra y las provincias Vascongadas, una vez restablecida la Constitución de 1812, continua discurriendo en cierta manera bajo los mismos parámetros que ya se habían observado en el anterior periodo constitucional, aunque en este caso, es posible, que acentuados, al ser más conscientes del significado de las reformas constitucionales en detrimento de los fueros, después de la primera experiencia liberal.

Al proceder, de nuevo, a la jura de la Constitución, mientras que Navarra ${ }^{117}$ y Álava ${ }^{118}$ no opusieron ninguna resistencia y reserva a la misma, las Juntas Generales de Guipúzcoa y Vizcaya volvieron a oponerse al juramento. Las primeras, de forma más expresa y conscientes de su significado en contra de los Fueros después de la primera experiencia constitucional, y las segundas, sin oponer grandes obstáculos, volvían a repetir los mismos planteamientos de que el texto constitucional no hacía

Rey, es más fácil instruirse ellos con los libros, que ya se dice haber en el país, que no el que novecientas mil almas que habrá en Cataluña deban mudar sus costumbres y prácticas... tanta repetición de Constituciones, de práctica de costumbres y de naturales en diferentes leyes, no parece que pueda dejar de obedecerse por la débil razón de que diez, veinte o treinta jueces que deben venir de fuera han de instruirse en los libros del país" (Ibidem, p. 75-77).

${ }^{113}$ El citado autor examina los pronunciamientos de los distintos ayuntamientos (Ibidem, pp. 77 y 78).

${ }^{114}$ Idem, p. 78.

${ }^{115}$ Idem, pp. 79 y 80.

${ }^{116}$ Idem, p. 80.

${ }^{117}$ Mina Apat, op. cit., pp. 77-79.

${ }^{118}$ Irigoras Alberdi, op. cit., p. 69. 
sino que recoger el espíritu de la constitución vizcaína ${ }^{119}$. Actitud que contrasta, de nuevo, con el proceder de los Ayuntamientos de Bilbao y San Sebastián, que juraron sin reserva alguna el texto gaditano.

Al margen de las reticencias expresadas por parte de las Juntas Generales citadas, la transición del régimen foral al constitucional se operó en términos similares a como había acontecido en la primera experiencia liberal. Las nuevas diputaciones, elegidas en mayo de 1820, continuaron compuestas, en su mayor parte, por personalidades que habían venido controlando tradicionalmente las instituciones provinciales. Ahora bien, el nuevo periodo supuso un cambio sustancial con respecto del anterior: durante el Trienio la aplicación del régimen constitucional fue realmente efectivo, lo que provocaría el desmantelamiento del régimen foral ${ }^{120}$.

Retomada la senda del texto gaditano, se procedió a dar los primeros pasos en orden al desarrollo del art. 258 del mismo. Se promulgó un Código penal y se elaboró un primer proyecto de Código civil ${ }^{121}$. Con respecto de este último, al parecer, según resalta Irigoras Alberdi, la Diputación de Vizcaya se pronunció con el objeto de defender parte de su sistema de Derecho civil foral, al menos, en el ámbito del Derecho de sucesiones, alegando para ello el interés que podría ofrecer al resto de los territorios este aspecto particular del derecho civil vascongado. Argumentaciones que, como hemos podido comprobar, encajan perfectamente con los planteamientos mantenidos de forma reiterada por las Juntas Generales de Vizcaya y Guipúzcoa, al considerar que los sistemas forales, tanto en su vertiente pública como en la privada ${ }^{122}$, respondían a los principios fundamentales del liberalismo, y en consecuencia, este sistema debería de adoptarse como modelo de unificación del conjunto de los territorios.

Esta primera defensa, aunque fuera de parte de su derecho civil, exteriorizada en estos momentos, se puede interpretar de la siguiente manera:

En lo tocante a este pronunciamiento expreso con respecto a la materia civil que no hemos observado anteriormente, al menos en la anterior experiencia constitucional, se explicaría, en cierta manera, como consecuencia de que es ahora, precisamente, cuando se están llevando a cabo las primeras iniciativas para desarrollar el precepto

${ }^{119}$ Irigoras Alberdi, op. cit., p. 69. Rubio Pobes, quien además alude a la propuesta de la junta vizcaína, la cual, ante la falta de uniformidad entre ambos textos, propuso una transacción, un arreglo foral (rechazado de forma radical más tarde), siempre y cuando no afectara al régimen interior de administración del Señorío. Además, resalta que dicha transacción debía realizarse entre la Corona y el Señorío, al no reconocer cuerpo intermedio alguno, lo que viene a constatar, a juicio de la autora, la incomprensión total de lo que significaba el régimen constitucional. Incomprensión que se transformó en manifiesto rechazo, una vez que la experiencia del Trienio permitió llegar a entenderlo (Revolución y tradición ..., p. 150).

${ }^{120}$ Rubio Pobes, Revolución y tradición..., p. 151.

${ }^{121}$ Peset Reig, quien ha analizado este primer proyecto de Código Civil, resalta que la excesiva ambición de sus autores habría exigido un largo periodo de varios años para su redacción, lo que supuso que la obra quedara inacabada (Análisis y concordancias del proyecto de código civil de 1821, Anuario de Derecho Civil, XXVIII, fascículo 1 (enero-marzo 1975), p. 34).

${ }^{122}$ Irigoras Alberdi, op. cit., p. 72. 
constitucional relativo a la codificación en esta materia, con la elaboración del primer proyecto de código. Situación que no se había dado antes, y más aún cuando según resalta el prof. Peset, basándose en el discurso preliminar y en el índice del libro tercero del proyecto que no se llegó a redactar, se dejó para el final el tratamiento de las sucesiones, al presentar variedades forales, aunque no pensaban recogerlas ni se tenía decidido por cual se inclinarían ${ }^{123}$.

En lo que concierne a la admisión de una posible reforma foral en el ámbito del derecho civil, cabe decir que esta actitud transaccional se puede englobar dentro de ese movimiento más amplio, al que antes se alude con respecto al régimen foral en su conjunto ${ }^{124}$, que se manifiesta por las Juntas Vizcaínas en estos momentos como novedad, pero que, como se recoge anteriormente, será rechazado de forma radical más tarde.

Las experiencias vividas durante el Trienio permitieron comprender a la sociedad de los territorios forales que sus esperanzas de compatibilidad entre Constitución y Fueros no eran compartidas por el gobierno liberal. El rechazo difuso o ambiguo y las actitudes conciliadoras con respecto de las reformas constitucionales, esgrimidas durante el primer periodo de vigencia del texto gaditano, se convirtieron en estos momentos en una oposición decidida y firme, pospuesta por el restablecimiento del absolutismo, y que se manifestará ya de forma evidente en el periodo 1834-1837 125 .

La restauración de la monarquía absoluta, liquidado el Trienio, conllevó el retorno de la política ensayada por Fernando VII durante el periodo 1814-1820, centrada en el fortalecimiento del poder regio, en detrimento de los sistemas forales. El monarca adoptaría una serie de medidas, principalmente de carácter económico o dirigidas a un mayor control sobre los territorios, que encontraron una respuesta inmediata de rechazo por parte las provincias forales y que en su mayor parte se resolverían a favor de las estas últimas. Sin embargo, sería en este periodo cuando se logró un avance importante en la unificación del derecho con la promulgación del Código de Comercio de 1829, aprobación que, al parecer, no encontró gran resistencia por parte de los territorios con legislación particular ${ }^{126}$. Escasa oposición que podría explicarse en

123 "Sin salir de España para recorrer la legislación antigua o moderna de otros países, sin remontarse dentro de la misma España a tiempos lejanos, presentan hoy día un cuadro muy variado en esta parte sus diferentes provincias, en medio de la unidad de principios políticos. Navarra, las provincias Vascongadas, Aragón, Cataluña e Islas Baleares se diferencias de las Castilla en el particular, mucho más que en su clima y producciones. La Comisión ha meditado detenidamente la materia, y aunque el art. 258 la autorizaba para dictar modificaciones locales, creyó no debía adoptar otra que la de toda reforma saludable, la de no dar un efecto retroactivo (op. cit., p. 98).

${ }^{124}$ Ver nota 119.

${ }^{125}$ Rubio Pobes, Revolución y tradición ..., p. 151. Irigoras Alberdi, op. cit., p. 74.

${ }^{126}$ Tal y como señala Roca y Trias, "con anterioridad al Proyecto de Código Civil de 1851, que no entra en vigor por la oposición de los juristas de las zonas nacionales con un Ordenamiento civil propio, se había producido un hecho sobre el cual la doctrina catalana no ha hecho nunca suficiente hincapié: en 1829 se unifica el Derecho mercantil español con la promulgación del Código de Sainz de Andino, que 
razón de la naturaleza de este tipo de derecho, más abierto a lo supranacional y en consecuencia con menor arraigo entre las capas sociales ${ }^{127}$; así como a la confluencia de intereses existente en este campo tanto de absolutistas como de liberales.

Con independencia de la unificación mercantil, deseada por las distintas opciones políticas ${ }^{128}$; es cierto que, tal y como había ocurrido en el periodo absolutista anterior, el monarca en ningún momento persiguió acabar con los fueros, aunque si modificarlos en favor de sus intereses. Por otro lado, los territorios forales continuaron con la táctica de resistencia al poder real, que será utilizada igualmente contra el Estado liberal. Como muy bien señala Rubio Pobes, sería "precisamente esa elasticidad del Fuero, su capacidad de adaptación y la ambigüedad de su definición, que permitían presentarlo tanto como modelo de código liberal o como quintaesencia de un régimen jerárquico, facilitó su supervivencia en un siglo tan convulso y contradictorio como fue el siglo XIX" 129 .

La debilidad que caracterizó al poder real supuso como contrapartida un fortalecimiento del régimen foral, que le permitiría enfrentar el siguiente periodo constitucional con una fuerza de la que había carecido en los periodos anteriores.

\section{Conclusiones}

Expuestos aquellos hechos relevantes que se producen en los territorios Vascongados, Navarra y Cataluña durante el periodo 1808-1833, de ellos podemos inferir las siguientes conclusiones:

En primer lugar, insistir que el sentimiento y pronunciamientos de defensa de sus particularidades jurídicas por parte principalmente de los territorios Vascongados, Navarra y Cataluña, no dejan de aparecer en todos aquellos momentos en que se procede a impulsar reformas que pudiera afectar a las mismas. Así se ha podido observar tanto en la génesis y aprobación de la Constitución de Bayona y de Cádiz, como en los momentos en que el poder absoluto adopta medidas en este sentido.

Es cierto que tales medidas podrían considerarse de tenues, de poco consistentes, ya que, de hecho, en pocos momentos adquirieron una dimensión suficiente como para impedir los propósitos ideados por el gobierno de turno, pero ello no significó

dando suprimido un cuerpo importantísimo de Derecho foral comercial... supresión que no levantó ninguna protesta en Cataluña" (El Código civil y los Derechos nacionales..., p. 15). Ver también J. Rubio, Sainz de Andino y la codificación mercantil, Madrid, 1950, p. 108.

127 "El comercio busca el beneficio de los comerciantes que no puede verse limitado por los localismos nacionalistas; la racionalidad abstracta e impersonal se impone en el derecho mercantil" (A. Iglesia Ferreirós, La Creación del Derecho. Una historia de la formación de un derecho estatal español, Manual II, Barcelona, 1992, p. 493). También en parecidos términos se pronuncia J. Rubio, "En segundo lugar, la facilidad de su puesta en vigor desde el punto de vista político, ya que la falta de arraigos locales en un derecho nuevo por definición, apartaba todo problema foral" (op. cit., p. 108).

${ }^{128}$ Así lo destaca F. Tomás y Valiente (Manual de Historia del Derecho Español, Madrid, 1996, p. 509).

${ }^{129}$ Rubio Pobes, op. cit., p. 160. 
una asunción consciente por parte de los citados territorios de la pérdida, más o menos extensa en función de los mismos, de su particularidad jurídica.

Esta tenue o reducida dimensión de la respuesta a las reformas aprobadas en contra de los particulares ordenamientos jurídicos vigentes, lo que no significa que no existiera, se debió como ya adelantábamos en la introducción de este trabajo, no tanto a la inexistencia de apego a sus particularismos "he hecho una fiel pintura del horror que causaría a los pueblos cercanos al Pirineo la pérdida de sus leyes, libertades, fueros y lengua..." ${ }^{130}$, como a distintas motivaciones que posiblemente empañaron la verdadera realidad.

Tales motivaciones fueron de diversa índole:

1. El ambiente y la situación que vivía el país, tanto en el momento de enfrentarse a las reformas propuestas por Napoleón como más tarde por las Cortes de Cádiz, no facilitaba para nada una oposición decidida y firme a las mismas. No debemos olvidar la situación de prestigio y poder que rodeaba a la figura del emperador, primero, y posteriormente la situación de guerra ante la ocupación francesa, así como el sentimiento patriótico nacionalista de lucha contra lo extranjero que ello generó. Este ambiente vivido, como es razonable pensar, no fue propicio para enfrentarse a los designios de una figura de la talla de Napoleón y más tarde para pensar en particularismos, cuando lo inminente era conseguir la unidad para vencer a la ocupación extranjera. Todo ello se condensa en la siguiente frase del guipuzcoano Zumalacárregui: "lo importante en estos momentos era ganar la guerra y no un planteamiento de la cuestión foral en Cortes"131.

La situación bélica incidiría, asimismo, en la elección de diputados a las Cortes de Cádiz en aquellas provincias ocupadas. Al no poder proceder según las normas establecidas, se acordó su designación, como ha quedado expuesto, entre los naturales de aquellas provincias residentes en Cádiz. Evidentemente, aquellos que se encon-

\footnotetext{
${ }^{130}$ Palabras recogidas en el contraproyecto ordenado por la corte española a Izquierdo, tal y como destaca M. Artola en Los afrancesados (Madrid, 1989, p. 80).

${ }^{131}$ Irigoras Alberdi, Derechos históricos vascos y constitucionalismo español: foralidad y sistema jurídico liberal en el siglo XIX, Oñati, 2008, p. 61. Son muy significativas para comprender la realidad del momento y la actitud de los territorios con derecho propio ante la labor de las Cortes gaditanas, las siguientes palabras de Camps y Arboix, que transcribo a continuación: "En resumen: juzgar el grado de regionalismo, particularmente jurídico, de los constituyentes catalanes de Cádiz bajo el prisma de hoy en día, se incurriría indudablemente en el desfoque que significa el querer modernizar el pasado. Pero, si tenemos en cuenta que, como dice Soldevila, todos los esfuerzos de la Cataluña de entonces se reducían a su aspiración de convertirse en provincia; con un idioma depauperado, inepto por su anarquía gramatical a ser lengua de cultura; con un derecho que si era vivo y fructífero, en las esferas intelectuales hacía figura de atrasado; con un imperativo histórico definido por las circunstancias que impedía toda reivindicación política de mayor alcance, si todo este complejo de cosas tenemos en cuenta, habremos de convenir que exigir más de aquellos ínclitos varones sería pretensión excesiva. Bástenos, pues, valorarlos en su junto medio; bástenos añadir un eslabón más en la cadena de la historia del Derecho catalán formada por la voz de sus hombres representativos y por las manifestaciones reales de la conciencia de su pueblo" (op. cit., p. 60).
} 
traban en la ciudad gaditana simpatizarían con los planteamientos liberales y, por tanto, serían proclives a la reforma; lo que podría explicar la pasividad de los mismos a la hora de defender la conservación de sus particulares sistemas jurídicos, al margen del sentimiento patriótico antes señalado.

2. Por otro lado, creo que ha quedado clara en la anterior exposición la falta de comprensión del significado y alcance de los principios liberales que se denota en la mayor parte de la sociedad española. Extremo que se observa desde los primeros momentos del periodo y que se mantendrá en los años sucesivos. Así lo podemos comprobar tanto en cuanto a los diputados presentes en la Asamblea de Bayona, como más tarde en las respuestas a la consulta evacuada por la Junta Suprema Central; en las que si bien, en su mayoría, se pronuncian a favor de la unificación legal, pero lo hacen sin ser conscientes de lo que suponía la codificación de acuerdo con los principios del iusnaturalismo racionalista, y más en la línea de una nueva recopilación de leyes que acabara con los defectos de la Novísima. En definitiva, sin renunciar al mantenimiento de los particularismos jurídicos, los cuales, bien a través de un proceso de armonización con el resto de las instituciones vigentes, o bien como excepciones particulares podrían quedar incluidos en el código unificado propuesto. Desconocimiento que queda constatado, asimismo, en la actitud ambigua mostrada, principalmente por los territorios vascongados, en el momento de la aceptación y jura de la Constitución de 1812. Actitud que les lleva incluso a plantear la existencia de identidad entre Constitución y Fueros. Ejemplo claro de ello, lo encontramos en los pronunciamientos reiterados de las Juntas Generales de Vizcaya y Guipúzcoa, al considerar que los sistemas forales, tanto en su vertiente pública como privada, respondían a los principios fundamentales del liberalismo, y como consecuencia, este sistema debería adoptarse como modelo de unificación para el conjunto del territorio. Esta ingenuidad y desconocimiento de lo que el liberalismo significaba, explicaría, como ha señalado Rubio Pobes $^{132}$, que en unas mismas posiciones políticas encontremos a políticos liberales convencidos y futuros destacados fueristas. Situación, que comenzará a cambiar tras las primeras experiencias vividas durante el Trienio liberal, al constatar que esta compatibilidad entre Fueros y Constitución no era compartida por el gobierno. Aunque también es cierto que esta ambigüedad que caracterizó a los representantes de los territorios forales continuó durante el periodo absolutista posterior, al presentar en estos momentos los Fueros como modelo de adecuación al nuevo sistema imperante.

Esta elasticidad para considerar a los Fueros como modelo de liberalismo, o esencia del sistema jerárquico, demuestra claramente la lucha constante por la supervivencia de los mismos.

3. Otro aspecto a destacar es la ausencia de desarrollo y aplicación práctica de los postulados constitucionales, debido a las convulsiones políticas a que estuvo sometido el país durante las primeras décadas del siglo, lo que implicó un desconocimiento ab-

${ }^{132}$ Op. cit., p. 138. 
soluto del alcance efectivo de las reformas. Esta inexistente vigencia efectiva de los nuevos postulados, como señalábamos anteriormente, experimentará un cambio durante el Trienio Liberal, lo que, de acuerdo con los planteamientos que venimos defendiendo, elevará el grado de contestación en contra de las reformas y en defensa de los postulados foralistas. Respuesta que se pospondrá durante el restablecimiento del absolutismo, para retornar con un vigor ya imparable a partir de la muerte de Fernando VII y el restablecimiento del sistema constitucional.

Íntimamente relacionado con este último aspecto, y cuestión fundamental para el objeto de este trabajo, es la carencia de actuaciones concretas en orden a la codificación civil durante el periodo, con la excepción del proyecto de 1821 (no concluido). El mantenimiento, sin merma alguna, de todas aquellas instituciones vigentes en los distintos territorios, hacían innecesaria, al carecer de objeto, cualquier tipo de respuesta. El principio recogido en el art. 258 de la Constitución gaditana, no experimentará desarrollo alguno en el periodo examinado, con la sola salvedad de una inclusión, cada vez mayor, del número de representantes procedentes de Cataluña en las sucesivas comisiones designadas para elaborar los códigos. Si a todo ello añadimos que, como consecuencia de esta falta de desarrollo del mismo, no existe un perfil claro y definido de la forma en que se va a llevar a cabo la unificación propuesta, si atendiendo a las instituciones forales o no, (de nuevo el único ensayo se encuentra en el proyecto de 1821, cuyo libro III, que sería el que mayor incidencia tuviera en los derechos privados de los territorios forales no se llegó a redactar) es bastante comprensible la ausencia de manifestaciones concretas en este sentido.

Por último, para terminar, insistir en la idea repetida a lo largo de todo el trabajo: la moderada contestación contra las reformas y el reducido grado de intensidad de la misma se pueden atribuir a todos aquellos condicionamientos que se dieron en la época y que hemos tratado de señalar anteriormente; pero del análisis de los acontecimientos examinados, creo, que se puede colegir claramente que el arraigo y apego de los territorios con derecho propio al mismo era grande, existió y no desapareció y, por tanto, aunque latente, estaba ahí para servir de plataforma de despegue cuando la realidad cambia y las políticas del gobierno central comienzan a crear situaciones de verdadero riesgo para la permanencia de los mismos. 